\title{
THE
}

\section{Origin of the Louisville Ridge and its relationship to the Eltanin Fracture Zone System}

\author{
A. B. Watts \\ J. K. Weissel \\ R. A. Duncan \\ R. L. Larson \\ University of Rhode Island
}

Follow this and additional works at: https://digitalcommons.uri.edu/gsofacpubs

Terms of Use

All rights reserved under copyright.

\section{Citation/Publisher Attribution}

Watts, A. B., J. K. Weissel, R. A. Duncan, and R. L. Larson (1988), Origin of the Louisville Ridge and its relationship to the Eltanin Fracture Zone System, J. Geophys. Res., 93(B4), 3051-3077, doi: 10.1029/ JB093iB04p03051.

Available at: http://dx.doi.org/10.1029/JB093iB04p03051

This Article is brought to you for free and open access by the Graduate School of Oceanography at DigitalCommons@URI. It has been accepted for inclusion in Graduate School of Oceanography Faculty Publications by an authorized administrator of DigitalCommons@URI. For more information, please contact digitalcommons-group@uri.edu. 


\title{
Origin of the Louisville Ridge and Its Relationship to the Eltanin Fracture Zone System
}

\author{
A. B. Watts ${ }^{1}$ and J. K. Weissel \\ Lamont-Doherty Geological Observatory, Palisades, New York \\ R. A. Duncan \\ College of Oceanography, Oregon State University, Corvallis \\ R. L. LARSON \\ Graduate School of Oceanography, University of Rhode Island, Kingston
}

\begin{abstract}
We have combined shipboard and Seasat altimeter derived data in an intergrated geological and geophysical study of the Louisville Ridge; a $3500-\mathrm{km}$-long seamount chain extending from the Tonga trench to the Eltanin Fracture Zone. A break in the smooth trend of the ridge at latitude $37.5^{\circ} \mathrm{S}$ has been recognized in both bathymetric and altimetric data. The ${ }^{40} \mathrm{Ar}-{ }^{39} \mathrm{Ar}$ dating of rocks dredged either side of the break suggest that it is analogous to the bend in the Hawaiian-Emperor seamount chain. Although the general trend of the ridge can be fit by small circles about Pacific absolute motion poles determined from other seamount chains, the new bathymetric and age data allow us to refine Pacific absolute motion poles. The continuity in smooth trend of the ridge and the Eltanin Fracture Zone suggests some relationship between them. However, a major offset developed on this transform between 60 and $80 \mathrm{Ma}$, prior to the oldest dated rocks from the ridge. Although magmatism was more or less continuous on the ridge during 28-60 Ma, it probably occurred on crust with little or no offset. Thus magmatism appears to have been little influenced by the developing fracture zone. By $28 \mathrm{Ma}$, the distance between the magmatic source and the fracture zone had decreased sufficiently for a portion of the ridge to have been emplaced on crust with an offset. After about $12 \mathrm{Ma}$, however, volcanic activity on the Louisville Ridge apparently waned, despite a possible influence on the magmatism of the fracture zone.
\end{abstract}

\section{INTRODUCTION}

The Louisville Ridge (Plate 1) is a prominent bathymetric feature in the southwest Pacific Ocean basin. (Plate 1 can be found in the separate color section in this issue.) The ridge is approximately $3500 \mathrm{~km}$ long and represents a volcanic lineament comprising a number of short ridges, isolated peaks, and flat-topped seamounts [e.g., Mammerickx et al., 1974] The ridge rises $3-4 \mathrm{~km}$ above the average depth of the seafloor. The ridge is aseismic, but apparently where it intersects at the Tonga-Kermadec trench it influences the pattern of regional seismicity [e.g., Giardini and Woodhouse, 1986].

Hayes and Ewing [1971] suggested that the Louisville Ridge was an extension of the Eltanin Fracture Zone system. They showed that the ridge lies close to a great circle connecting the Tonga-Kermadec trench with the Eltanin Fracture Zone. Hayes and Ewing [1971] argued that a break in the trend of the ridge at $40^{\circ} \mathrm{S}, 166^{\circ} \mathrm{W}$ reflected the change in orientation of seafloor spreading in the Pacific Ocean basin prior to formation of anomaly 32 . They implied that the Louisville Ridge was a fracture zone ridge and that it was Late Cretaceous or greater in age.

A similar view for the origin of the Louisville Ridge was held by Larson and Chase [1972]. They suggested, however, that the Eltanin Fracture Zone system extended farther north

\footnotetext{
${ }^{1}$ Also at Department of Geological Sciences, Columbia University, New York.
}

Copyright 1988 by the American Geophysical Union.

Paper number 6B6165.

0148-0227/88/006B-6165\$05.00 and that it terminated on a ridge and trough feature at the western edge of the Phoenix lineations in the central Pacific basin. Larson and Chase [1972] showed that the Louisville Ridge, the Phoenix ridge and trough, and the Eltanin Fracture Zone system could all fit a small circle about a pole of rotation similar to that inferred by Hayes and Ewing [1971].

Clague and Jarrard [1973] pointed out that the smooth trend of the Louisville Ridge is approximately copolar with the Emperor and Hawaiian seamounts chains. The Emperor seamounts had been shown in previous studies [e.g., Clague and Dalrymple, 1975] to have formed by motion of the Pacific plate over the Hawaiian hot spot. Clague and Jarrard [1973] proposed that the Louisville Ridge was similar in age to the Emperor seamounts $(42-70 \mathrm{Ma})$ and that it also formed by motion of the Pacific plate over a hot spot. Implicit in this suggestion is that during this time, the Louisville and Hawaiian hot spots remained fixed with respect to each other.

In a subsequent discussion, Molnar et al. [1975] pointed out that the topography of the ridge more closely resembled that of a linear seamount chain than a fracture zone. They also argued that since Australia and Antarctica separated at anomaly 34 time [Christoffel and Falconer, 1972], it was unlikely that the Eltanin Fracture Zone extended into oceanic crust that formed at the Pacific/Antarctica plate boundary since then. Thus, in the view of Molnar et al. [1975], the Louisville Ridge formed by processes similar to those that control the evolution of other linear seamount chains in the Pacific, such as the Hawaiian-Emperor chain.

Epp [1978] reviewed the age data along the HawaiianEmperor seamount chain and the bathymetric trends of individual seamount chains in the Pacific Ocean. He concluded 
TABLE 1. Principal Sources of Data

\begin{tabular}{ll}
\hline \multicolumn{1}{c}{ Institution } & \multicolumn{1}{c}{ Ship } \\
\hline Lamont-Doherty Geological Observatory & $\begin{array}{l}\text { Vema, Conrad, Eltanin } \\
\text { Oceanographer }\end{array}$ \\
$\begin{array}{l}\text { National Oceanic and Atmospheric } \\
\text { Administration (NOAA) }\end{array}$ & $\begin{array}{l}\text { Glomar Challenger } \\
\text { Deep Sea Drilling Project }\end{array}$ \\
$\begin{array}{l}\text { Institute of Oceanology } \\
\text { (Moscow, USSR) }\end{array}$ & Kana Keoki \\
Hawaii Institute of Geophysics & Tui \\
Defense Scientific Establishment & \\
(Auckland New Zealand) & ocean sounding charts \\
Hydrographic Office of the Royal & (multiple ships) \\
New Zealand Navy & Washington \\
Scripps Institution of & \\
Oceanography & \\
\hline
\end{tabular}

that most of the seamount chains on the Pacific plate could be attributed to a hot spot origin and that such a model could be used to predict their ages. In the case of the Louisville Ridge, Epp [1978] proposed that the break in trend at $40^{\circ} \mathrm{S}, 166^{\circ} \mathrm{W}$, first pointed out by Hayes and Ewing [1971], corresponded to the Hawaiian-Emperor bend. Since the age of the latter bend is reasonably well known, $E_{p p}$ [1978] used the hot spot model to predict ages along the Louisville Ridge. He proposed that the Louisville Ridge north of the trend break (which he identified at $\left.39.2^{\circ} \mathrm{S}, 167.5^{\circ} \mathrm{W}\right)$ was coeval with the Emperor seamounts (42-70 Ma), while the ridge to the south was similar in age to the Hawaiian Ridge between Midway and the bend (15-42 Ma).

Although the hot spot model has in the past been widely applied to the Louisville Ridge, there are few age determinations along the ridge to corroborate it. The only previously published age dates were those obtained by Ozima et al. [1970], which they pointed out represent minimum ages for the northernmost part of the ridge. Another difficulty is that the hot spot model does not explain the association of the Louisville Ridge either with the Eltanin Fracture Zone system or the Phoenix lineations ridge and trough feature.

In this paper we present the results of an integrated geological and geophysical study of the Louisville Ridge and its relationship to the Eltanin Fracture Zone System. The study is based mainly on data collected during shipboard geological and geophysical surveys of the region [Watts et al., 1985a; Hawkins et al., 1985] and during NASA's Seasat mission. The overall objective of this paper is to use this new data set to understand better the origin of the Louisville Ridge.

\section{DATA}

This study is mainly based on geological and geophysical data acquired by Lamont-Doherty Geological Observatory (LDGO) vessel R/V Vema during August and September 1979, Scrippss Institution of Oceanography's (SIO) vessel $\mathrm{M} / \mathrm{V}$ Washington during 1971 and 1985 and satellite radar altimeter data obtained during NASA's Seasat mission in 1978. We have also incorporated into the study shipboard data obtained by other institutions during 1963-1980 (Table 1) and satellite data obtained by NASA during the GEOS 3 mission in 1975 .

The shipboard data consist of bathymetry, gravity, singlechannel seismic reflection profile and magnetic data along individual ship tracks, and dredge hauls at selected sites. The shipboard data have been collected using different types of navigation. Prior to 1967 , the shipboard data were collected with celestial navigation. Since 1967, the U.S. Navy's satellite navigation system (TRANSIT) has been utilized. It is diflicult to assess the positional accuracy during the various shipboard surveys. It seems probable, however, that cruises which utilized satellite navigation should be accurate to about 0.1 nautical mile.

Bathymetry measurements were obtained with precision depth recorders (PDR). Typically, the bathymetry is sampled every $6 \mathrm{~min}$, corresponding to distances between individual data points of about $2 \mathrm{~km}$. In regions of high relief, however, the bathymetry is often sampled more frequently.

The gravity measurements were obtained with different instruments. The measurements obtained by LDGO, the Institute of Oceanology and SIO (since 1977) utilized a GrafAskania Gss-2 sea gravimeter mounted on a gyrostabilized platform, while the measurements obtained by NOAA, Hawaii Institute of Geophysics, and SIO (prior to 1977) utilized the Lacoste air-sea gravimeter mounted either in gimbals (prior to 1965 ) or on a gyrostabilized platform (since 1965). Studies of the discrepancy of gravity anomalies at intersection of ship tracks in the region [Davey and Watts, 1983] suggest that the gravity anomalies are accurate to about 5-10 mGal, depending on the type of navigation used. Typically, gravity anomaly values are calculated at 10 -min intervals, corresponding to distances between data points of about $3 \mathrm{~km}$.

Magnetic measurements were obtained by using a direct reading proton magnetometer towed behind a vessel. The total magnetic field observations were reduced to magnetic anomalies using the International Geomagnetic Reference Field (1971) as the background field.

The seismic reflection profiles were obtained with a singlechannel seismic streamer and an air gun sound source. Prior to 1979 , most of the cruises of LDGO vessels utilized a small sound source ( 20 cubic inches). The 1979 cruise of R/V Vema, however, utilized a larger sound source ( $2 \times 466$ cubic inches).

The satellite data consist of measurements of the sea surface height along individual satellite tracks of Seasat. A complete description of the instrumentation is given by Born et al. [1982]. The Seasat data are represented by 1-s averages of the sea surfaces height, which corresponds to distances between individual data points of about $7 \mathrm{~km}$. Corrections for instrument and atmospheric effects were applied [Lorell et al., 1980]. We did not correct the data for oceanographic effects which typically contribute less than $1 \mathrm{~m}$. Furthermore, no attempt was made to reduce sea surface height discrepancies at intersecting subsatellite tracks. These discrepancies are usually in the range $\pm 1 \mathrm{~m}$ to $\pm 2 \mathrm{~m}$ for one quarter of a revolution of Seasat. Thus over the study area in which $800-\mathrm{km}$-long profiles of altimeter data are used, these effects will be negligible.

\section{LOUisville RidGe}

\section{Bathymetry}

Figure 1 shows a bathymetry map of the Louisville Ridge between $25.5^{\circ} \mathrm{S}$ (intersection of the ridge and Tonga trench) and $44.0^{\circ} \mathrm{S}$. The map, which is based on all available bathymetry data over the ridge, is contoured at $1-\mathrm{km}$ intervals. The Louisville Ridge consists of ridge segments, isolated peaks, and ridge segments with superimposed isolated peaks. In general, there is a progression from ridge segments in the north- 


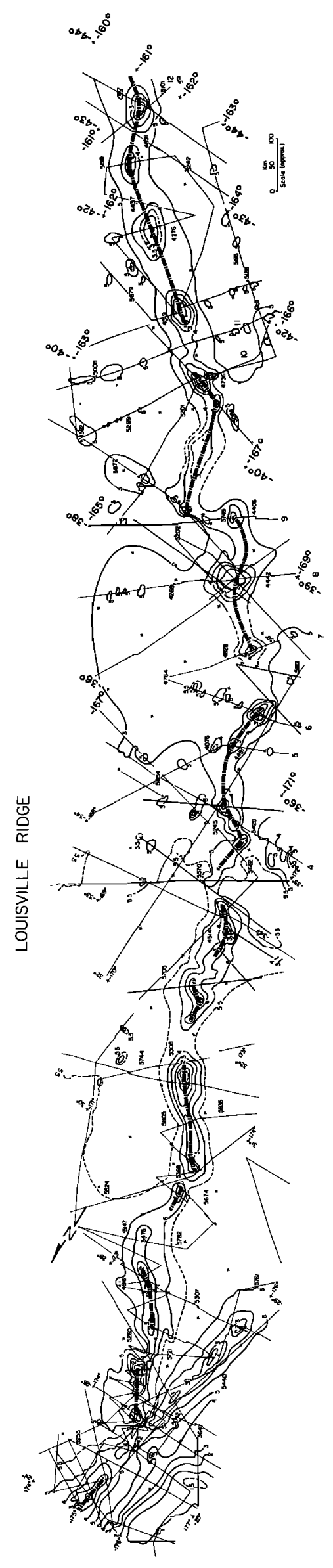

west to isolated peaks superimposed on ridge segments in the southeast.

The smooth trend of the ridge is NNW-SSE with a trend break at about $37.8^{\circ} \mathrm{S}$. Individual ridge segments trend, however, up to a few tens of degrees from the smooth trend. Associated with these changes in trends are abrupt ridge offsets, the most prominent of which occur at $29^{\circ} \mathrm{S}$ and $39^{\circ} \mathrm{S}$.

The bathymetry map in Figure 1 differs in several important respects from existing charts of the Louisville Ridge. For example, Mammerickx et al. [1974] show the ridge as discontinuous between $41.4^{\circ} \mathrm{S}$ and $43.5^{\circ} \mathrm{S}$, whereas Figure 1 , which is based on more data, shows the ridge as more or less continuous. Furthermore, significant differences between Mammerickx et al. [1974] and Figure 1 occur between $34^{\circ} \mathrm{S}$ and $37^{\circ} \mathrm{S}$.

Figure 2 illustrates the variation in bathymetry along the crest of the Louisville Ridge. The solid dots are minimum depths along the ridge crest, as inferred from bathymetry data in Figure 1. These values are supplemented by depths obtained by Soviet workers [Udintsev et al., 1963]. The open squares are mean depths obtained from data along individual profiles either side of the ridge. Figure 1 shows that the shallowest crestal and mean depths occur between latitude $36^{\circ} \mathrm{S}$ and $42^{\circ} \mathrm{S}$. (A minimum depth of $380 \mathrm{~m}$ is recorded at latitude $38.5^{\circ} \mathrm{S}$ ). Figure 1 shows, however, that the difference between the crestal and mean depth does not vary significantly along the ridge. The ridge is a more or less continuous feature which rises 3-4 km above the mean depth of the adjacent ocean floor.

The dashed line in Figure 2 indicates the expected depths based on the age of the seafloor in the vicinity of the ridge. North of about $34^{\circ} \mathrm{S}$, mean depths along the ridge are of expected values for their age. South of about $34^{\circ} \mathrm{S}$, however, mean depths are about $500 \mathrm{~m}$ shallower than expected.

The origin of the departures of observed from predicted depths along the Louisville Ridge is not clear at present. The unusually shallow bathymetry south of $34^{\circ} \mathrm{S}$ in Figure 2 correlates with a broad region of shallow depths mapped by Watts et al. [1985b] between New Zealand and Tonga. The shallow depths may be a result of variations in crustal thickness. Alternately, they represent one of the four ENE-WSW trending "belts" of shallow depths in the Pacific Ocean basin older than 80 m.y. which McKenzie et al. [1980] have suggested result from some form of small-scale convection in the Earth's mantle.

\section{Seismic Reflection Profiles}

Figure 3 shows the location of 12 seismic reflection profiles obtained by R/V Vema and USNS Eltanin over the Louisville Ridge (Table 2) during 1971-1979. The profiles illustrated in Figure 4 show that the Pacific Ocean basin flanking the Louisville Ridge is associated with a thin, acoustically "transparent" layer overlying a very strong reflector. A similar layer was mapped by Ewing et al. [1968] over other parts of the Pacific basin. They suggested this layer represented sediments that had accumulated in the Pacific during the Cenozoic. The strong reflector is generally irregular suggesting that it represents or at least closely follows the upper surface of the oceanic crust. On some profiles in the vicinity of the ridge, however, the reflector is smoother. In these regions it may represent either a layer within the volcanoclastic infill adjacent to the ridge or a volcanic layer contemporaneous in age with the 


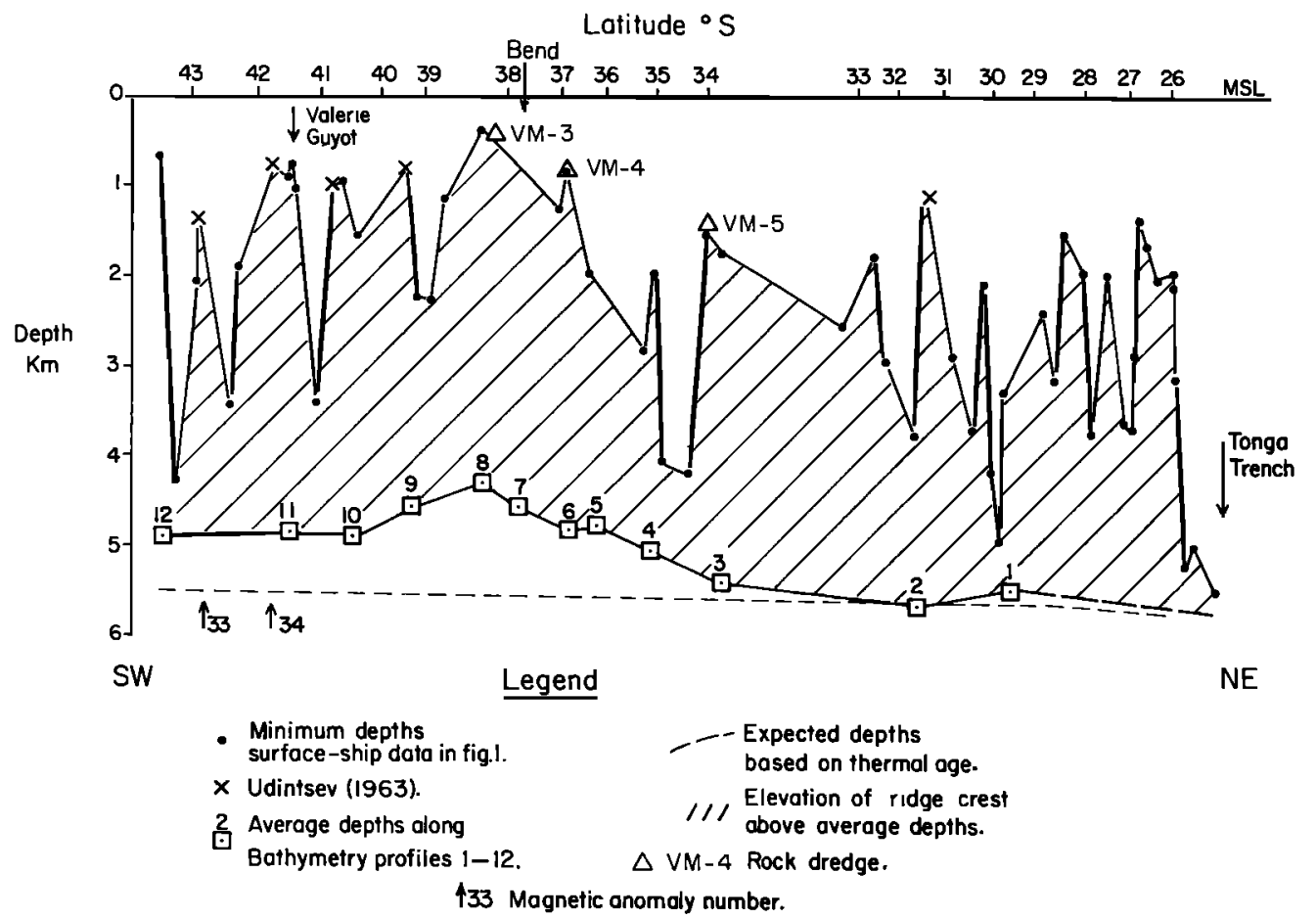

Fig. 2. Minimum depth profile along the crest of the Louisville Ridge. The data sources are the same as Plate 1 with the addition of Soviet measurements [Udinsev et al., 1963]. Also shown are average depths calculated from profiles 1-12 of the ridge (Figure 3), average free air gravity anomaly, and expected depths based on the thermal age of the underlying oceanic lithosphere.

ridge. The Louisville Ridge itself is associated with a very strong reflector and only on a lew profiles is there any evidence of sediment on the ridge flank or summit.

A detailed seismic reflection profile of the Louisville Ridge and its flanking region are shown in Figure 5. On this profile the transparent layer is associated with a two-way travel time of about $0.2 \mathrm{~s}$, suggesting a layer thickness of about $100 \mathrm{~m}$. A maximum layer thickness of $750 \mathrm{~m}$ is suggested in the "moat" flanking the southwest slope of the ridge. Underlying the transparent layer is a strong irregular reflector which in places protrudes through the seafloor. It is likely that this reflector represents the top of the oceanic crust. We believe that the smooth strong reflector, which extends between strong reflector peaks, represents either volcanoclastic material shed from the ridge or volcanic material contemporaneous in age to the ridge.

\section{Free Air Gravity Anomaly and Topography Profiles}

We show 12 free air gravity anomaly and topography profiles of the Louisville Ridge in Figure 6. The ridge is associated with a large-amplitude gravity anomaly "high" of 50-180 $\mathrm{mGal}$ and flanking gravity anomaly "lows" of 10-20 mGal. Typically, the width of the gravity anomaly high is $50-100 \mathrm{~km}$. The flanking lows are broader, reaching about $200-\mathrm{km}$ widths on profiles 1 and 2 .

In general, there is a strong correlation between changes in free air gravity anomaly and topography along the Louisville Ridge. A notable exception occurs on the southwest end of profile 9 where the gravity anomaly is relatively low over a topography high. On profiles 4 and 5 there are two prominent gravity anomaly highs southwest of the smooth trend of the ridge. These highs correlate with a shallowing of the topography (A, B) and probably represent two seamounts which are isolated from the ridge.

\section{Magnetic Anomaly Profiles}

Figure 7 shows selected magnetic anomaly profiles over the Louisville Ridge. The profiles show a variable pattern of anomalies that range from -200 to $+400 \mathrm{nT}$ amplitude over the ridge crest. Profiles 2, 3, 4, 6, 7, and 11 show a negative anomaly over the ridge, while profiles $1,5,8,9,10$, and 12 show a positive anomaly. We interpret this variable pattern as a result of the formation of the ridge during alternate polarity periods of the Earth's magnetic field.

\section{Geoid}

As a result of NASA's GEOS 3 and Seasat missions, extensive coverage of geoid data now exists over the Louisville Ridge and its vicinity. Marsh et al. [1984] compiled the satellite-derived geoid data into a new map of the marine geoid. Haxby et al. [1983] used gridded geoid slopes from Seasat measurements to compute a satellite-derived gravity map of the world's oceans. Plate 2 shows these gravity anomalies in the region of the Louisville Ridge.

We have found that a useful way to illustrate geoid data for tectonic studies is as geoid anomaly and/or geoid slope profiles along individual satellite tracks. Figure 8 shows 26 selected descending satellite crossings of the Louisville Ridge from Seasat. We chose these crossings because they are at high angles to the smooth trend of the ridge. Moreover, they extend over portions of the ridge where there are little or no surface 


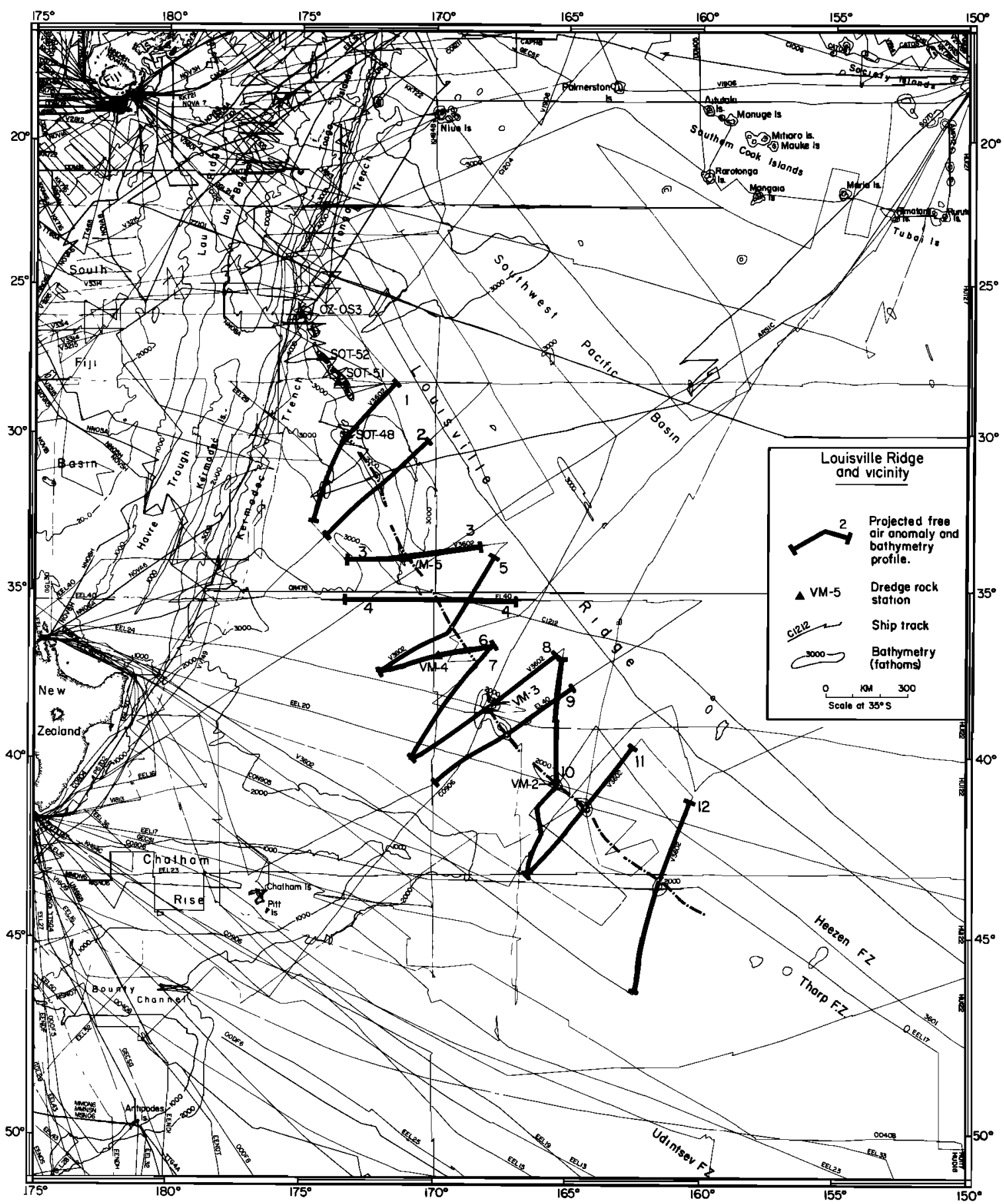

Fig. 3. Location map showing all available ship tracks along which bathymetry data were obtained. Tracks of the New Zealand Defense Scientific Establishment and Royal Navy for which only limited digital data were available are omitted from the map. The heavy lines locate projected bathymetry, as well as free air gravity anomaly, profiles 1-12 in Figure 6. The bathymetry is shown at 1000 -fathom intervals and is based on the work by Chase et al. [1971]. The heavy dash-dot line locates the crest of the Louisville Ridge based on Plate 1.

ship data. Figure 9 shows geoid anomalies along each satellite track. The geoid anomalies were computed by subtracting Seasat-derived geoid heights from a GEM 10 geoid reference field complete to degree and order 12 . On repeat Seasat satellite tracks, only geoid anomalies along the first in the repeat sequence have been plotted. Figure 9 shows that the Louisville
Ridge is associated with a prominent geoid high of 3-6 m flanked by lows of $1-2 \mathrm{~m}$. The widths of the high are $100-150$ $\mathrm{km}$. As was the case for the free air gravity anomaly, the widths of the flanking lows exceed those of the high by as much as $100 \mathrm{~km}$.

An important result shown in Figure 9 is that the Louisville 
TABLE 2. Principal Facts of Seismıc Reflection and Projected Free Air Gravity Anomaly and Bathymetry Profiles 1-12

\begin{tabular}{|c|c|c|c|c|c|c|c|}
\hline \multirow[b]{2}{*}{ Profile } & \multirow[b]{2}{*}{ Cruise } & \multicolumn{2}{|c|}{$\begin{array}{c}\text { Position of } \\
\text { Projection Point }\end{array}$} & \multicolumn{2}{|c|}{$\begin{array}{l}\text { Mean Values } \\
\text { Along Profile }\end{array}$} & \multicolumn{2}{|c|}{$\begin{array}{l}\text { Bathymetry } \\
\text { Along Profile }\end{array}$} \\
\hline & & $\begin{array}{l}\text { Latitude } \\
{ }^{\circ} S\end{array}$ & $\begin{array}{c}\text { Longitude } \\
{ }^{\circ} \mathbf{E}\end{array}$ & $\begin{array}{c}\text { Free Air, } \\
\text { mGal }\end{array}$ & $\begin{array}{c}\text { Bathymetry, } \\
\text { m }\end{array}$ & $\begin{array}{c}\text { Minimum, } \\
\text { m }\end{array}$ & $\begin{array}{c}\text { Maximum, } \\
\text { m }\end{array}$ \\
\hline 1 & V3602 & 29.84 & 173.18 & 1.5 & 5473 & 4168 & 5904 \\
\hline 2 & EL40 & 31.69 & 172.16 & -10.1 & 5642 & 3667 & 6017 \\
\hline 3 & V3602 & 33.87 & 171.25 & 3.0 & 5417 & 1549 & 5874 \\
\hline 4 & EL40 & 35.24 & 170.38 & 4.1 & 5060 & 2818 & 5731 \\
\hline 5 & V3602 & 36.33 & 169.81 & 4.2 & 4773 & 1994 & 5612 \\
\hline 6 & V3602 & 36.89 & 169.85 & -2.2 & 4809 & 955 & 5334 \\
\hline 7 & V3602 & 37.69 & 168.98 & -6.8 & 4590 & 1246 & 5071 \\
\hline 8 & V3602 & 3850 & 168.03 & 11.6 & 4235 & 422 & 5390 \\
\hline 9 & EL40 & 39.22 & 167.24 & 18.4 & 4547 & 1194 & 5663 \\
\hline 10 & V3602 & 40.66 & 165.38 & 14.7 & 4890 & 897 & 5591 \\
\hline 11 & V3602 & 41.40 & 164.26 & 1.2 & 4815 & 792 & 5487 \\
\hline 12 & V3602 & 43.50 & 161.53 & -1.0 & 4902 & 837 & 5368 \\
\hline
\end{tabular}

Ridge extends south of $43.5^{\circ} \mathrm{S}$ (the latitude of the intersection of profile 12 with the smooth trend of the ridge) to at least $45.3^{\circ} \mathrm{S}$. The character of the geoid anomaly on profile 26 (Figure 9), for example, closely resembles that of profiles 19-21 over the central portion of the ridge. However, the geoid anomaly on profiles 24 and 25 is more subdued and does not resemble the seamount-type geoid anomaly seen elsewhere along the ridge. Thus, while the ridge appears to continue south of $43.5^{\circ} \mathrm{S}$, it may not be as continuous as to the north.

\section{GEOCHRONOLOGY}

Volcanic rocks have been dredged from a number of locations along the Louisville Ridge and from the isolated seamounts which lie along the southeastern extension of the ridge (see heavy arrows, Plate 2). Samples were collected by Scripps's South Tow expedition, by the more recent Scripps's Marathon expedition and the Lamont-Doherty cruises described in this paper. Acknowledgement of the specific source of the samples is made in Table 3. Radiometric dating of this unusually complete collection was undertaken to determine the age relationship of the volcanism on the ridge to the underlying oceanic lithosphere.

The dredged rocks obtained during the Lamont-Doherty cruises were obtained from the flanks of the ridge (Figure 4). Sepcific locations of the Scripps's samples are described elsewhere [Lonsdale, this 1ssue; Hawkins et al. [1987]. All samples were examined in thin sections to assess their textures and extent and type of alteration. Most of the rocks are holocrystalline alkalic basalts, containing olivine and often porphyritic pyroxene and plagioclase. One sample contained fresh pyroxene which could be separated for K-Ar dating. Some specimens are highly vesicular, while others are compact. Full petrological and geochemical analysis of the samples will be published elsewhere [Hawkins et al., 1987].

All samples exhibited some degree of low-temperature seawater alteration of mesostasis and phenocrysts to green-brown smectites, with calcite and zeolites filling veins and vesicles. This alteration process generally involves diffusive loss of argon from the primary igneous phases [Dalrymple and
Clague, 1976] and net addition of potassium to the rocks during clay and zeolite formation [Scheidegger and Stakes, 1977; Honnorez, 1981]. Both effects will decrease the measured $\mathrm{K}-\mathrm{Ar}$ age relative to the crystallization age. In contrast, ${ }^{40} \mathrm{Ar}-{ }^{39} \mathrm{Ar}$ total fusion ages on samples with similar lowtemperature alteration give consistent and reliable estimates of crystallization age [Dalrymple et al., 1981; Duncan, 1984; O'Connor and Duncan, 1984].

Ozima et al. [1970] have attempted to date volcanic rocks dredged from Osbourn Seamount, at the extreme northwest end of the ridge, using the conventional K-Ar method. The reported ages in that study range from 30 to $36 \mathrm{Ma}$ and are considered minimum estimates of that seamount's age in view of the seawater alteration effects.

The measured ${ }^{40} \mathrm{Ar}^{-}{ }^{39} \mathrm{Ar}$ total fusion ages (Table 3), however, are consistent and show a systematic distribution within this volcanic province. Sample preparation, irradiation conditions, and analytical methods are the same as those described by Duncan [1982] and Dalrymple et al. [1981]. Generally high proportions of radiogenic argon were measured which yielded precise calculated ages (1-2\% uncertainties). Replicate measurements on independent splits of three of the samples yielded nearly identical ages.

In Figure 10 we summarize the ages along the Louisville Ridge. Figure 10 shows that there is a clear decrease in volcano age from northwest $(66-68 \mathrm{Ma})$ to the southeast $(0 \mathrm{Ma})$. The age progression is, of course, similar to that of other volcanic lineaments on the Pacific plate. In particular, dated samples from the Hawaiian Ridge and Emperor Seamounts show the same age range (Suiko Seamount, $65 \mathrm{Ma}$, to Hawaii). Moreover, seamounts near the change in smooth trend of the Louisville Ridge are dated at $44-46 \mathrm{Ma}$, which is very near the estimated age of the Hawaiian-Emperor bend, $43 \mathrm{Ma}$ [Dalrymple and Clague, 1976]. The fresh pyroxene separate from V3602-4 yielded at $\mathrm{K}$-Ar age of $43.9 \pm 2.4 \mathrm{Ma}$, in good agreement with the ${ }^{40} \mathrm{Ar}-{ }^{39} \mathrm{Ar}$ whole rock age. The age data, then, support a hot spot origin for the Louisville Ridge, as originally proposed by Clague and Jarrard [1973] and more recently suggested by Watts et al. [1985a], Hawkins et al. [1985], and Lonsdale [this issue]. 


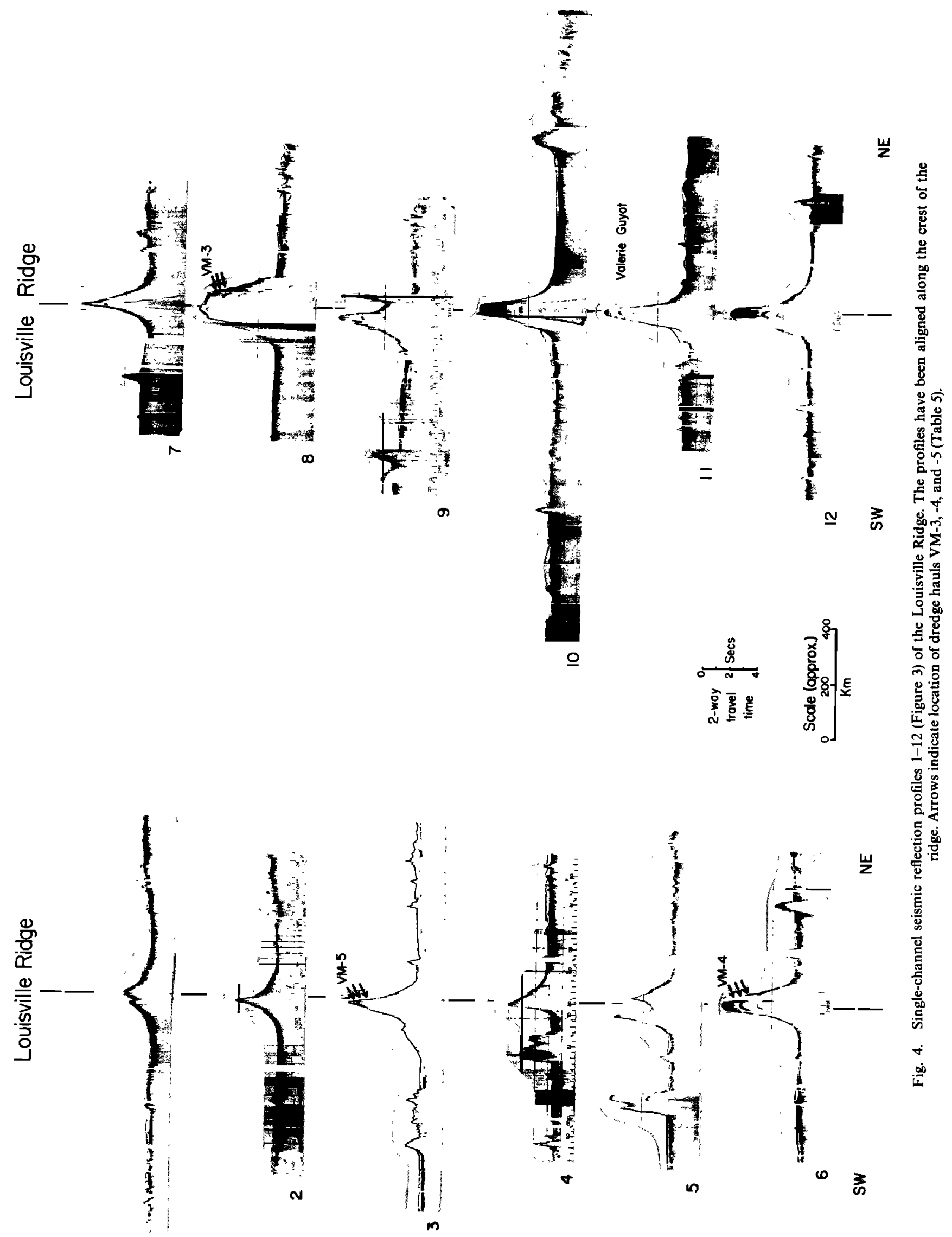




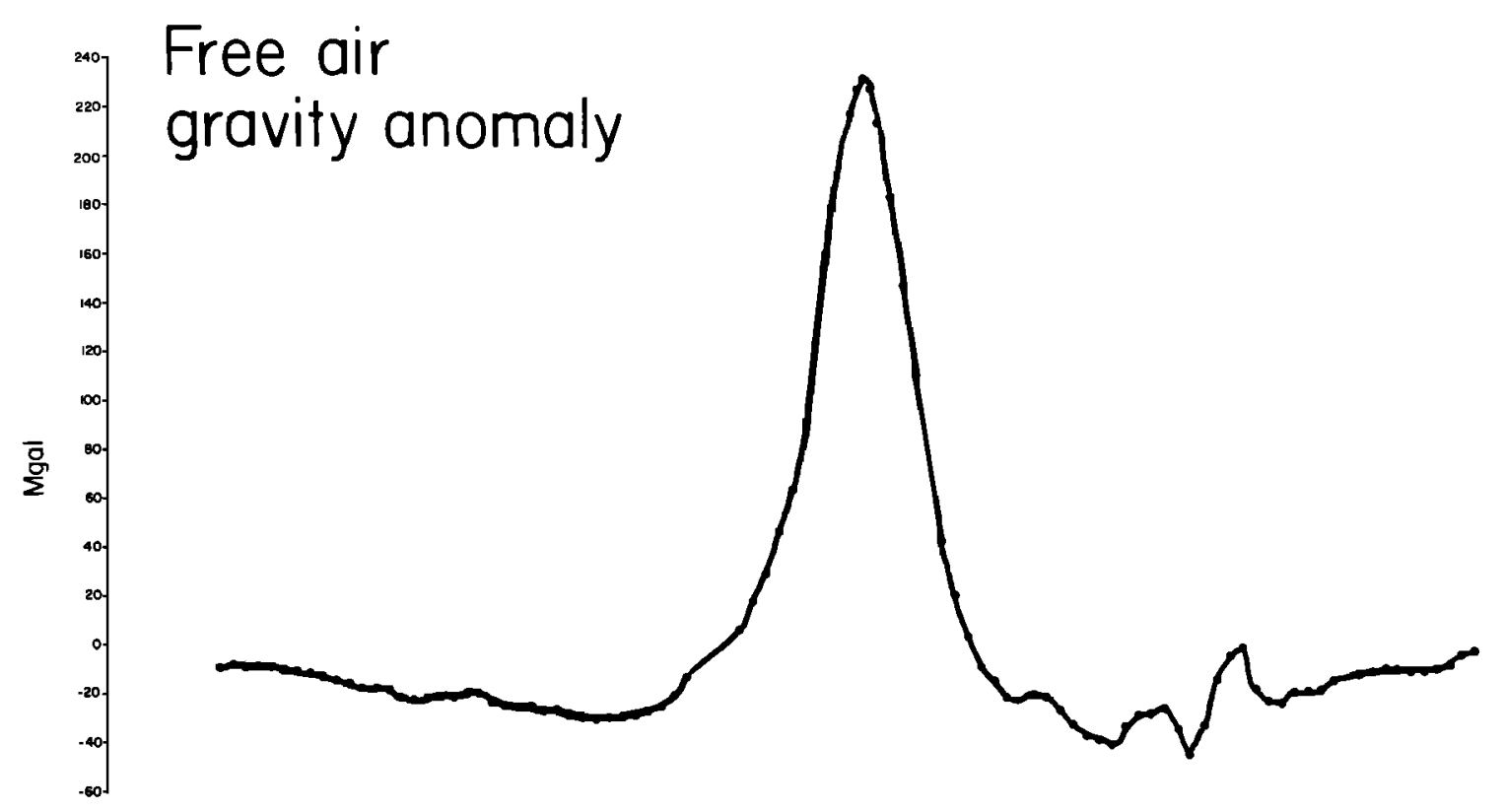

I Aug. 24

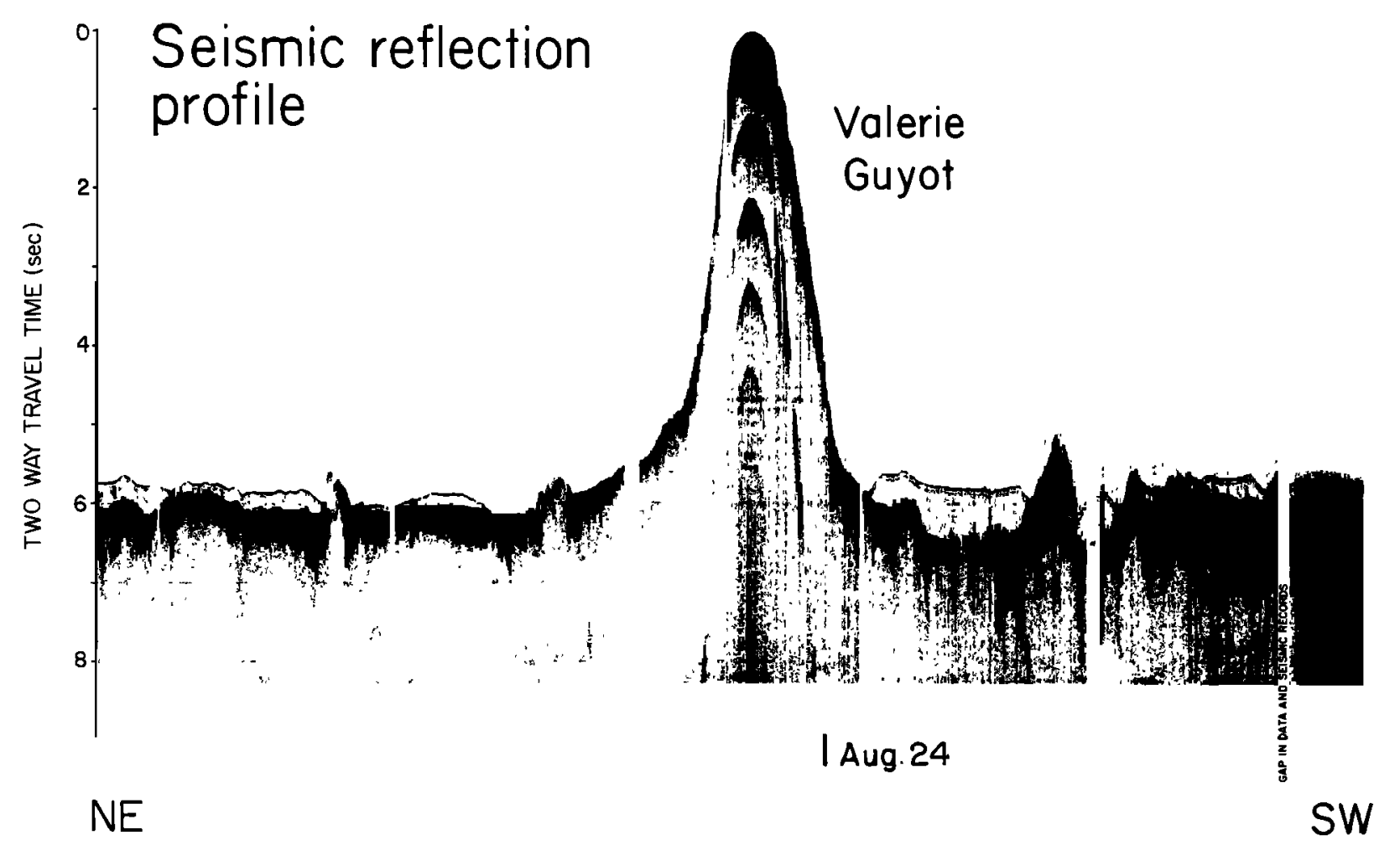

Fig. 5. Detalled free arr gravity anomaly and seismic reflection profile along profile 11 which crosses the Louisville Ridge in the vicinity of latitude $41.4^{\circ} \mathrm{S}$ (Valerie Guyot [Chase et al., 1972]). 


\section{Louisville Ridge}
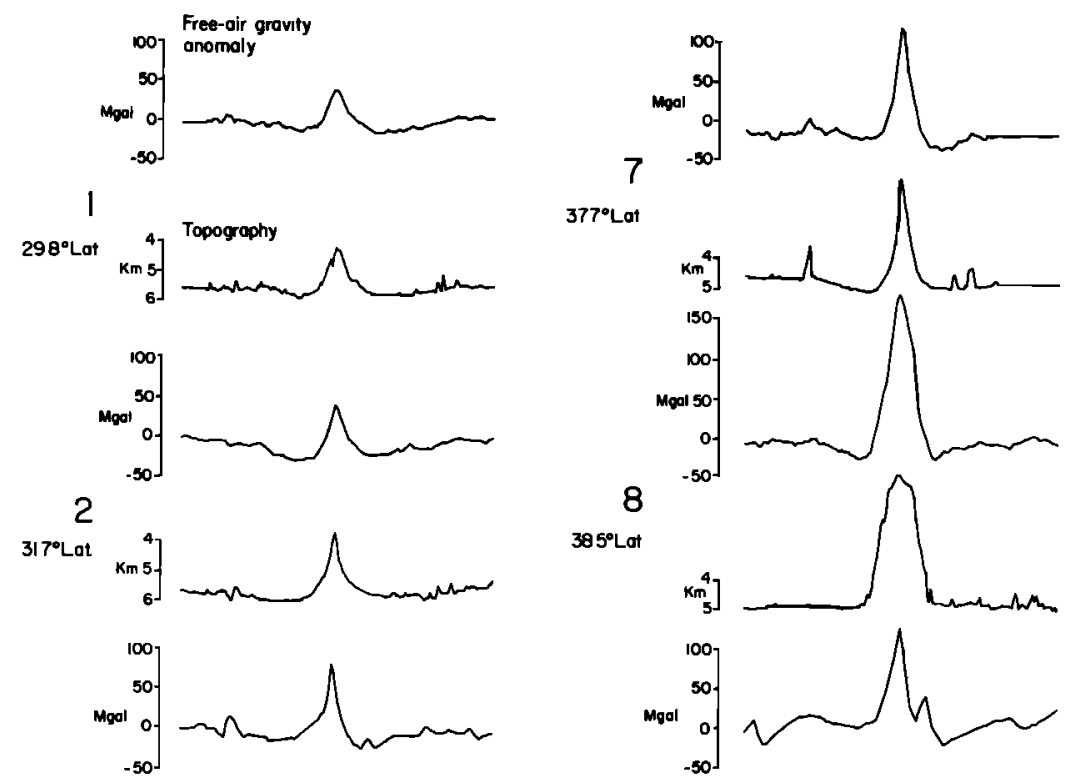

3

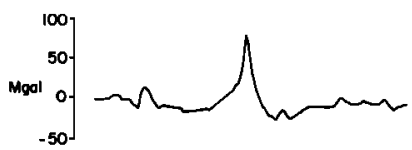

$339^{\circ}$ Lat
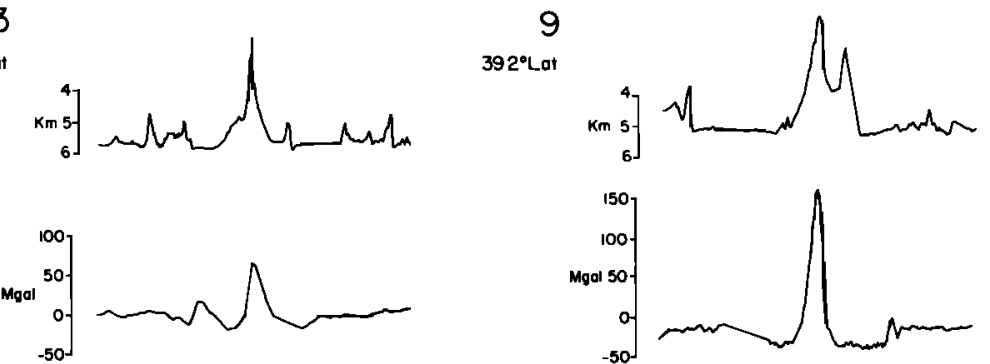

4

35.2'Lat
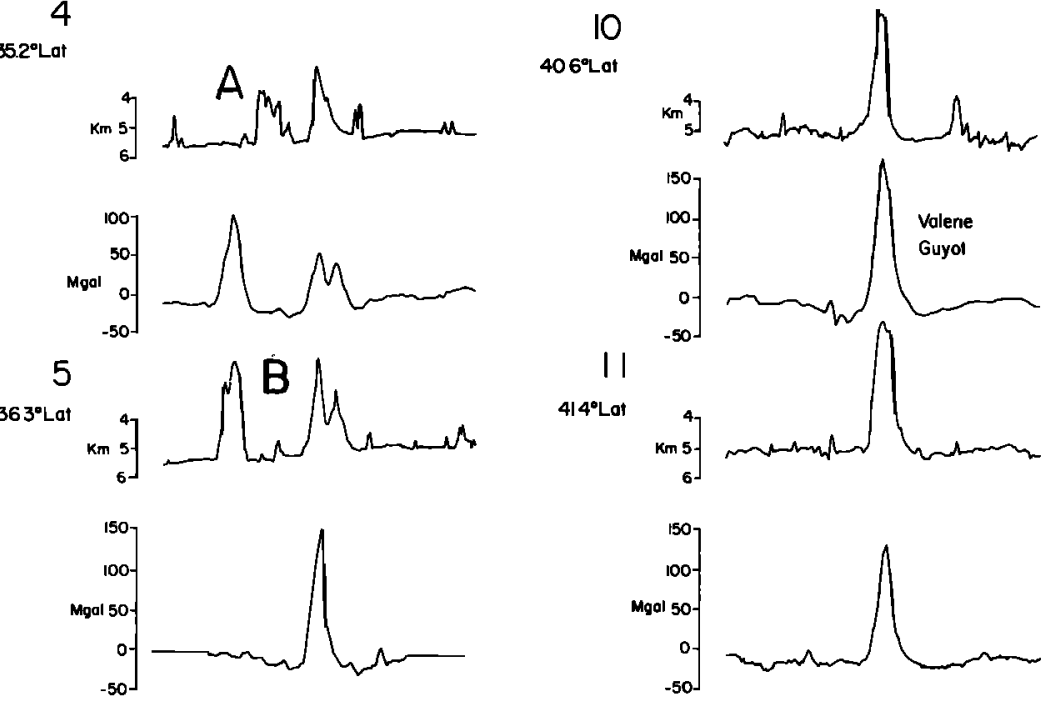

6

$369^{\circ}$ Lat
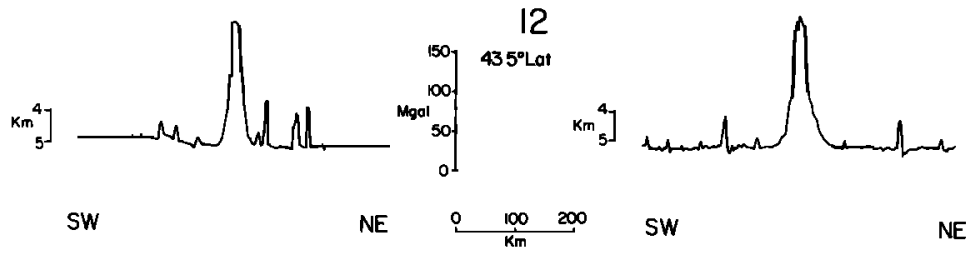

Fig. 6. Twelve projected free air gravity anomaly and bathymetry profiles of the Louisville Ridge between latitude $29.8^{\circ}$ and $43.5^{\circ}$. The principal facts for each profile are summarized in Table 2. 


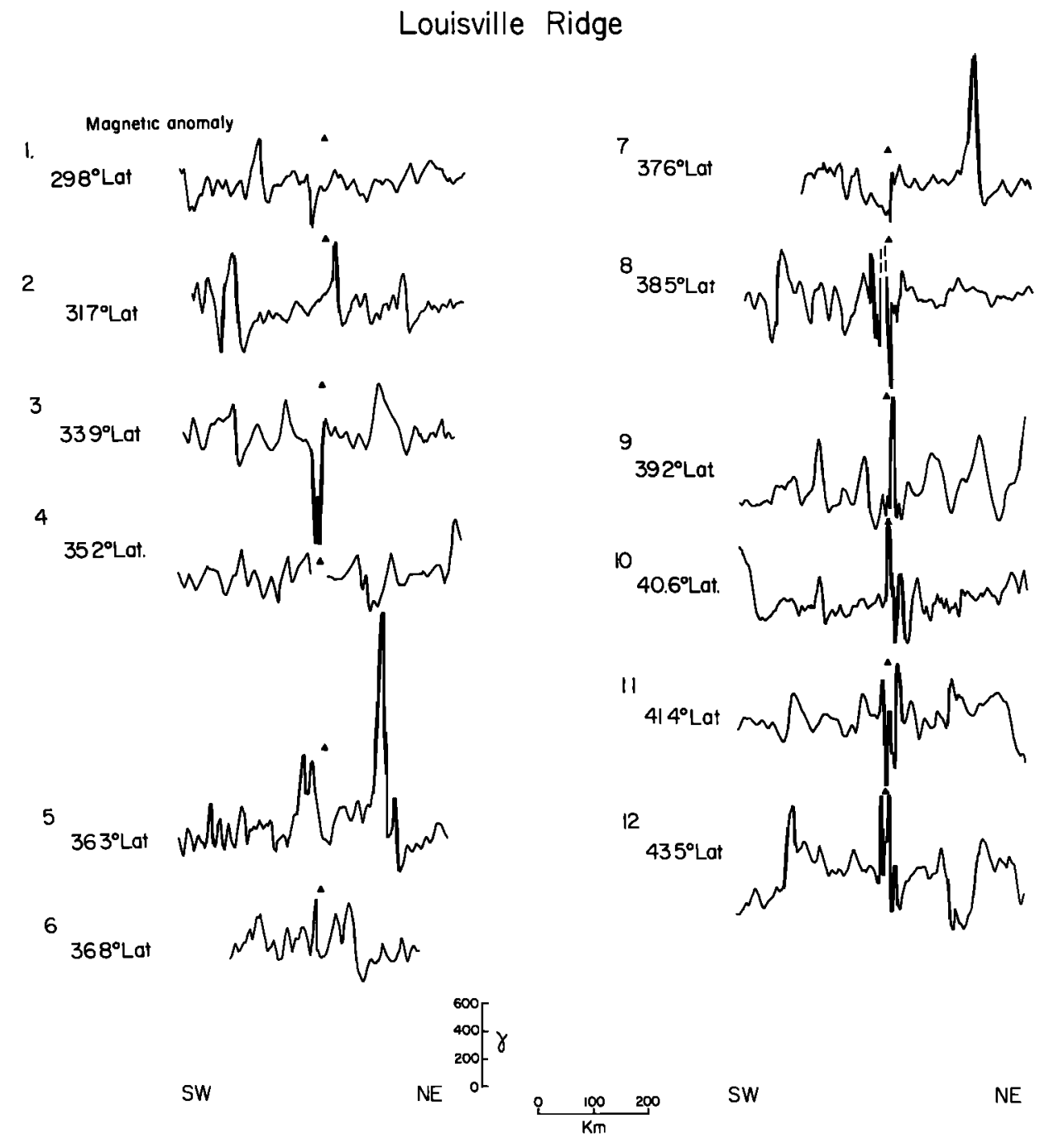

Fig. 7. Selected magnetic anomaly profiles over the Louisville Ridge.

\section{FLEXURE OF THE LITHOSPHERE}

Oceanic flexure studies have shown that the effective elastic thickness of the lithosphere, $T_{e}$, is a strong function of its thermal age at the time of loading [e.g., Watts et al., 1980]. Thus, by analyzing the relationship between free air gravity and topography along single profiles, it is possible to estimate the tectonic setting of volcanic loads on the ocean floor.

In order to estimate the setting of the Louisville Ridge, we analyzed the free air gravity anomaly and topography data in Figure 6 using cross-spectral techniques [e.g., Dorman and Lewis, 1970]. Each profile was used to obtain independent estimates of the cross spectrum and power spectrum. The smoothed spectra were then used to compute the coherence, phase of the admittance, and $\log _{10}$ of the amplitude of the admittance. Figure 11 shows that the coherence is relatively high ( $>50 \%$ ) for $0.02<k<0.4 \mathrm{~km}^{-1}$, suggesting that for wavelengths in the range of $12.5-314 \mathrm{~km}$, most of the energy in the gravity field is caused by the topography. For wavelengths greater than this range the coherence decreases because of isostasy, but for small wavelengths it decreases because of navigational uncertainties and instrument noise.

Figure 12 shows a plot of the admittance for $0<k<0.18$ $\mathrm{km}^{-1}$ compared to theoretical admittances based on the flexure model of isostasy. In the model we assumed that the Louisville Ridge represents a two-dimensional load on the surface of a thin elastic plate. A summary of all the parameters assumed in the models is given in Table 4. An overall "best fit" between observed and calculated admittance was obtained for $T_{e}$ in the range $15-35 \mathrm{~km}$.

Figure 13 shows that although observed admittance explains well the overall relationship between gravity and bathymetry along the Louisville Ridge, there are discrepancies in detail. In particular, residual gravity anomalies (observed minus calculated anomalies) are low flanking the northern portion of the ridge (e.g., north of $33.9^{\circ} \mathrm{S}$ ) and high flanking the southern portion (e.g., south of $45.3^{\circ} \mathrm{S}$ ). Since the admittance can be considered as a measure of the average flexural properties of the lithosphere, variations in residual gravity anomalies may therefore indicate variations in $T_{e}$ beneath the volacanic ridge.

In order to test this, we compared individual observed gravity anomaly profiles with calculated gravity profiles based on different values of $T_{e}$. The best fitting value of $T_{e}$ was determined by minimizing the sums of the squares between ob- 


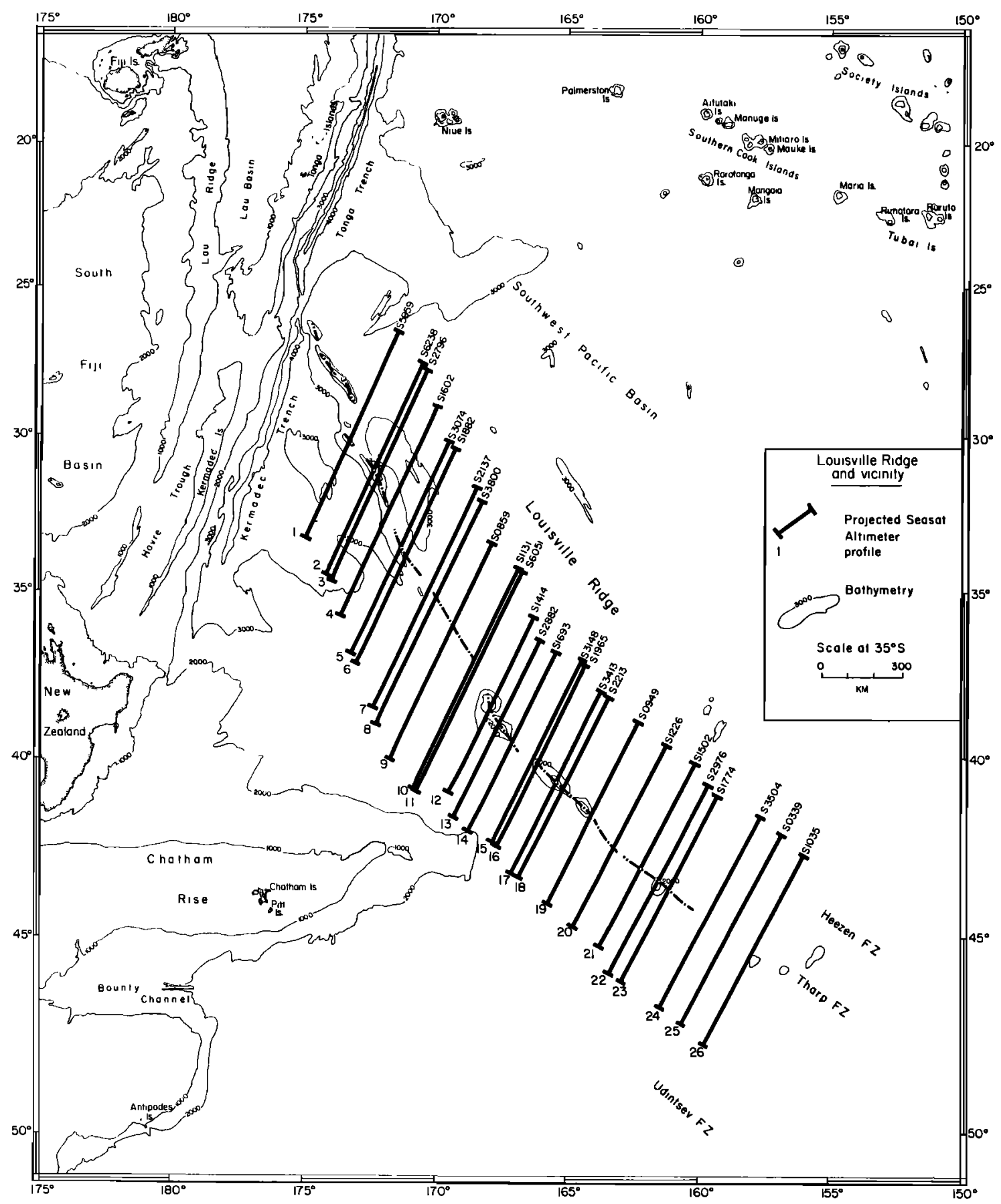

Fig. 8. Descending Seasat satellite radar altimeter tracks over the Louisville Ridge. The sea surface heights measured along each satellite track are shown in Figure 9. The track identifications are based on a Lamont-Doherty scheme and do not correspond to track identifications on the Jet Propulsion Laboratory user tape. Bathymetry is the same as Figure 3.

served and calculated gravity anomalies. Figures 14 and 15 illustrate the best fit for profiles 2 and 11 which traverse the ridge at $31.7^{\circ} \mathrm{S}$ and $41.4^{\circ} \mathrm{S}$, respectively. Figures 14 and 15 show that for the northern part of the ridge the best fitting $T_{e}$ (in a least squares sense) is about $15 \mathrm{~km}$, while for the southern part of the ridge it is about $40 \mathrm{~km}$. Thus $T_{e}$ appears to increase from the north to the south part of the ridge. This is further substantiated in Figure 16, which shows rms differences between observed and calculated anomaly values for each profile of the ridge. Figure 16 shows that while it is difficult on some profiles to estimate (e.g., $3,4,11), T_{e}$ is in the range of $10-20 \mathrm{~km}$ over the northern part of the ridge (open circles) and $25-45 \mathrm{~km}$ over the southern part (solid circles).

We caution, however, that the flexure model used to best fit the gravity anomaly data in Figures 12-16 assumes that the ridge extends infinitely normal to the profile (i.e., it is two dimensional). Thus we assume that the length of the ridge is much greater than its width. Unfortunately, the detailed 


\section{Louisville Ridge}

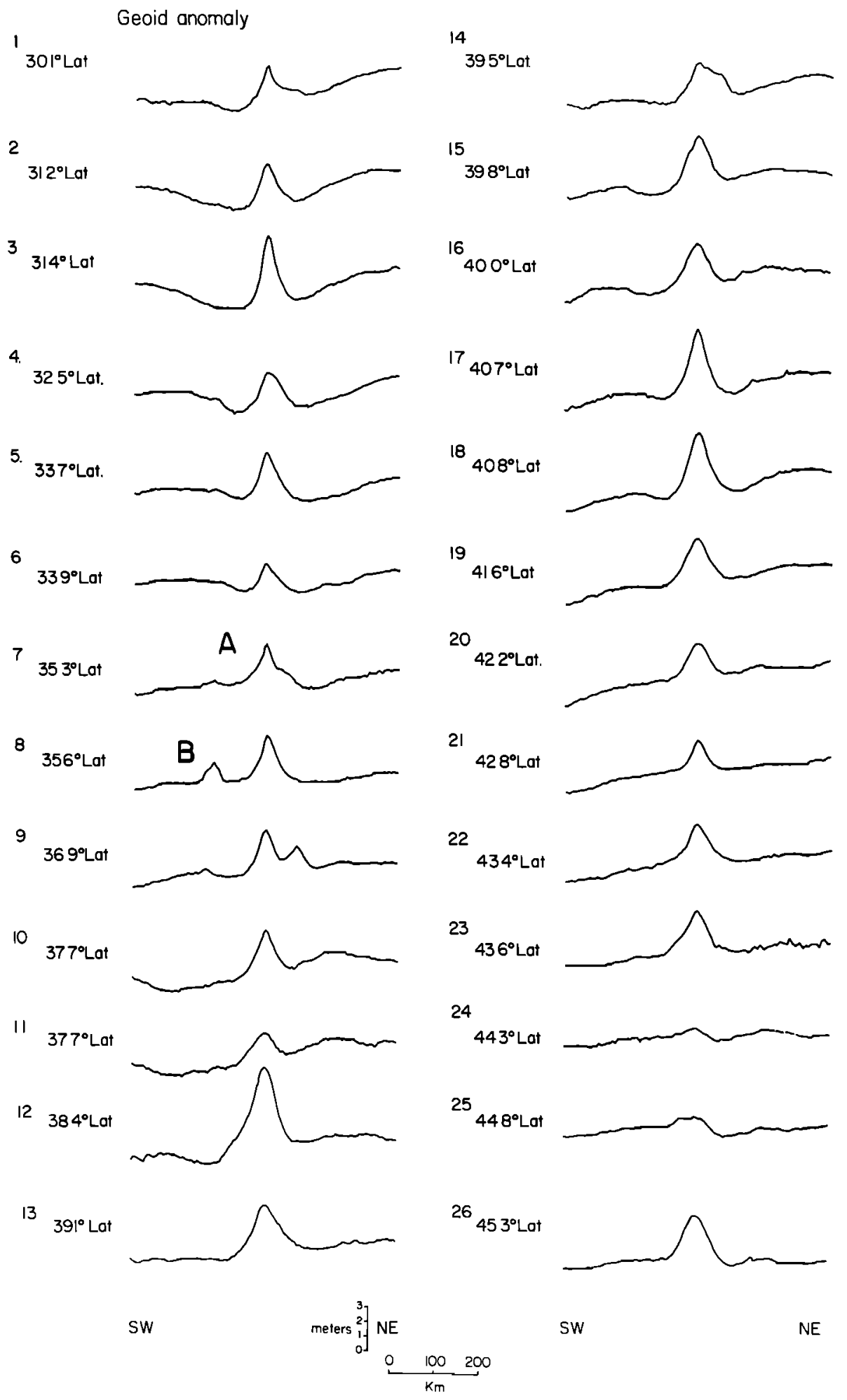

Fig. 9. Geold anomaly profiles derived from Seasat altimetry over the Louisville Ridge. The geoid anomaly was obtained by subtracting the measured sea surface height along each satellite subtrack from a GEM 10 reference field complete to degree and order 12 . The profiles have been aligned with respect to the geoid anomaly high, the peak value of which appears to correlate with the crest of the Louisville Ridge. 
TABLE 3. The ${ }^{40} \mathrm{Ar}-{ }^{39} \mathrm{Ar}$ Total Fusion Ages of Dredged Rocks From the Louisville Ridge

\begin{tabular}{|c|c|c|c|c|c|c|}
\hline Sample & Location & $\begin{array}{l}{ }^{40} \mathrm{Ar} / \\
{ }^{36} \mathrm{Ar}\end{array}$ & $\begin{array}{l}{ }^{40} \mathrm{Ar} / \\
{ }^{39} \mathrm{Ar}\end{array}$ & $\begin{array}{l}{ }^{37} \mathrm{Ar} * / \\
{ }^{40} \mathrm{Ar}\end{array}$ & $\begin{array}{l}\text { Percent } \\
\text { Radiogenic } \\
{ }^{40} \mathrm{Ar}\end{array}$ & $\begin{array}{l}\text { Age } \pm 1 \sigma \\
\times 10^{6} \text { years }\end{array}$ \\
\hline \multirow[t]{2}{*}{ SOTW9-58-1 } & $25^{\circ} 31.8^{\prime} \mathrm{S}, 175^{\circ} 02.4^{\prime} \mathrm{W}$ & 738.2 & 18.54 & 0.2201 & 60.0 & $65.9 \pm 0.6$ \\
\hline & & 674.1 & 20.01 & 0.0876 & 56.2 & $66.6 \pm 0.6$ \\
\hline \multirow[t]{2}{*}{ SOTW9-52-1 } & $27^{\circ} 16.8^{\prime} \mathrm{S}, 174^{\circ} 12.6^{\prime} \mathrm{W}$ & 439.9 & 39.62 & 0.0307 & 32.8 & $66.7 \pm 1.4$ \\
\hline & & 488.4 & 35.70 & 0.0573 & 38.3 & $70.1 \pm 1.4$ \\
\hline SOTW9-48-2 & $30^{\circ} 06.0^{\prime} \mathrm{S}, 173^{\circ} 15.0^{\prime} \mathrm{W}$ & 515.8 & 27.91 & 0.2216 & 42.7 & $61.2 \pm 0.9$ \\
\hline VM-5 & $33^{\circ} 56.7^{\prime} \mathrm{S}, 171^{\circ} 11.5^{\prime} \mathrm{W}$ & 356.6 & 54.39 & 0.1823 & 17.1 & $53.4 \pm 2.6$ \\
\hline VM-4 & $36^{\circ} 57.0^{\prime} \mathrm{S}, 169^{\circ} 50.0^{\prime} \mathrm{W}$ & 636.0 & 14.50 & 0.6625 & 53.5 & $44.6 \pm 0.5$ \\
\hline VM-3 & $38^{\circ} 19.5^{\prime} \mathrm{S}, 167^{\circ} 43.7^{\prime} \mathrm{W}$ & 838.3 & 29.79 & 0.4180 & 63.9 & $45.5 \pm 0.5$ \\
\hline \multirow[t]{2}{*}{ Valerie Guyot } & $41^{\circ} 36.8^{\prime} \mathrm{S}, 164^{\circ} 12^{\prime} \mathrm{W}$ & 504.2 & 14.77 & 0.1069 & 41.4 & $36.6 \pm 0.6$ \\
\hline & & 527.0 & 13.08 & 0.4745 & 43.9 & $34.4 \pm 0.6$ \\
\hline MTHN 6D-1 & $48^{\circ} 12^{\prime} \mathrm{S}, 148^{\circ} 48^{\prime} \mathrm{W}$ & 387.8 & 8.76 & 0.4521 & 23.8 & $12.5 \pm 0.4$ \\
\hline MTHN 7D-1 & $50^{\circ} 26^{\prime} \mathrm{S}, 139^{\circ} 09^{\prime} \mathrm{W}$ & 318.7 & 11.55 & 1.2195 & 7.3 & $0.5 \pm 0.2$ \\
\hline
\end{tabular}

Samples provided by J. Hawkins (SOTW 9-48, 52, 58; Valerie Guyot), A. B. Watts (VM-3, 4, 5), and P. Lorisdale (MTHN 6D, 7D).

The ${ }^{37} \mathrm{Ar}$ is corrected for decay since irradiation.

bathymetry of the ridge either side of profiles $1-12$ is so poorly known that the length/width ratio $\phi$ cannot be estimated with any certainty. Ribe [1982] has shown that there is a significant difference between theoretical admittance for two-dimensional (high $\phi$ ) and three-dimensional (low $\phi$ ) bathymetry, suggesting that the differences in $T_{e}$ inferred from Figure 16 may, in fact, result from variations in dimensionality along the ridge.

Figure 17 shows calculated gravity anomaly profiles over a $100-\mathrm{km}$-wide volcanic load based on different values of dimensionality and $T_{e}$. In Figure 17 a dimensionality of $\infty$ corresponds to a two-dimensional "ridge," while a dimensionality of $1: 1$ corresponds to a circular three-dimensional "seamount." A value of $T_{e}=11 \mathrm{~km}$ corresponds to a feature formed on or near a ridge crest, while $T_{e}=40 \mathrm{~km}$ corresponds to a feature formed off-ridge. The main result shown in Figure 17 is that in the case of $100-\mathrm{km}$-wide surface loads the gravity anomaly is a strong function of $\phi$.

For purposes of discussion, we show in Figure 17, as a dashed line, an observed gravity anomaly profile of the southern part of the ridge at latitude $41.4^{\circ} \mathrm{S}$ (profile 11, Figure 6). Figure 17 shows that while the observed gravity anomaly over the ridge could be explained by $T_{e}=40 \mathrm{~km}$, it could also be explained by a lower value depending on dimensionality. In particular, if the ridge is "two dimensional," a high value is preferred, but if it is composed of isolated circular seamounts, a low value of about $11 \mathrm{~km}$ would be preferred. Inspection of Figure 1 shows that the southern part of the ridge comprises isolated peaks superimposed on a more or less continuous ridge. Thus $T_{e}$ for profile 11 may be smaller than that deduced in Figure 15 assuming two dimensionality. In which case, $T_{e}$ may not necessarily be higher over the southern part of the ridge than the northern part.

Cazenave and Dominh [1984] recently estimated $T_{e}$ along the Louisville Ridge using a combined Seasat-derived geoid and U.S. Naval Oceanographic Office [Van Wyckhouse, 1973] bathymetry data set, SYNBAPS. Their data are based on gridded averages of geoid and bathymetry over the entire ridge system so that they incorporate dimensionality. The data set they used, however, is based on a grid spacing of about 10 feet $(3 \mathrm{~m})$ so that individual features in the geoid and bathymetry with wavelengths less than $25 \mathrm{~km}$ will be poorly resolved.
Moreover, it does not include the new bathymetric data used to compile the map in Figure 1.

Table 5 summarizes the estimates of $T_{e}$ obtained by Cazenave and Dominh [1984] and compares them to the estimates obtained in this study. Two sets of estimates are shown for the Cazenave and Dominh [1984] study: one based on the gridded data set (three dimensional) and one based on individual profiles of the ridge (two dimensional). A comparison with their estimates shows good agreement for the northern part of the ridge. In particular, the $T_{e}$ estimates of this study $(10-20 \mathrm{~km})$, which assume two dimensionality, agree with those of Caze-

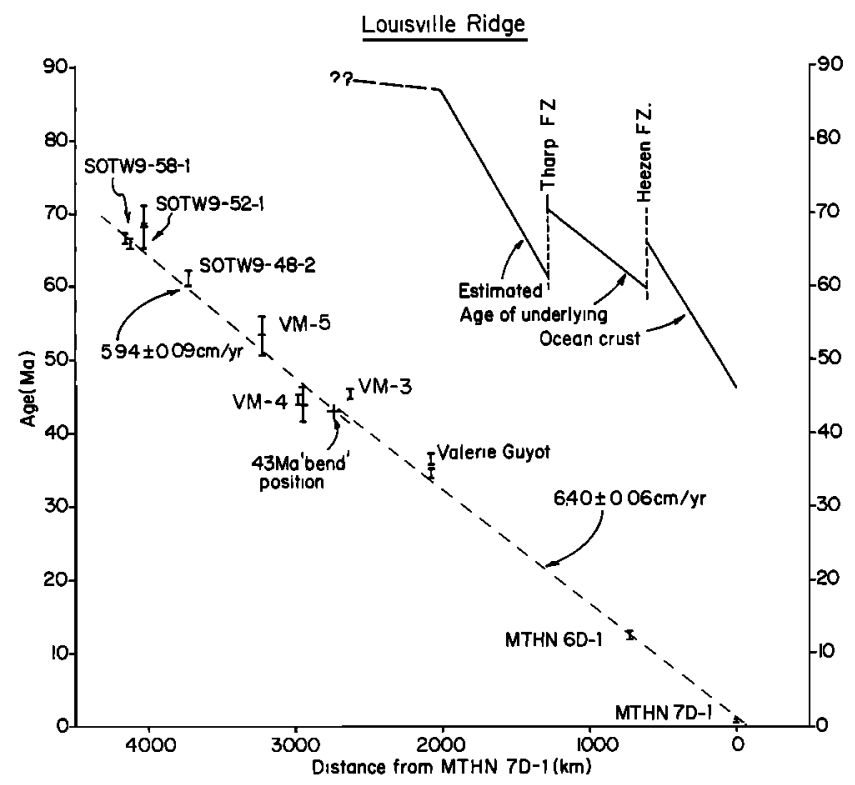

Fig. 10. Plot of age versus distance from the MTHN 7D-1 dredge site, at the southeast extremity of the Louisville Ridge. The sources of the data are summarized in Table 3. Also shown is a plot of estimated age of the underlying oceanic crust based on the magnetic and anomaly studies of Molnar et al. [1975], Weissel et al. [1977], and this paper. 

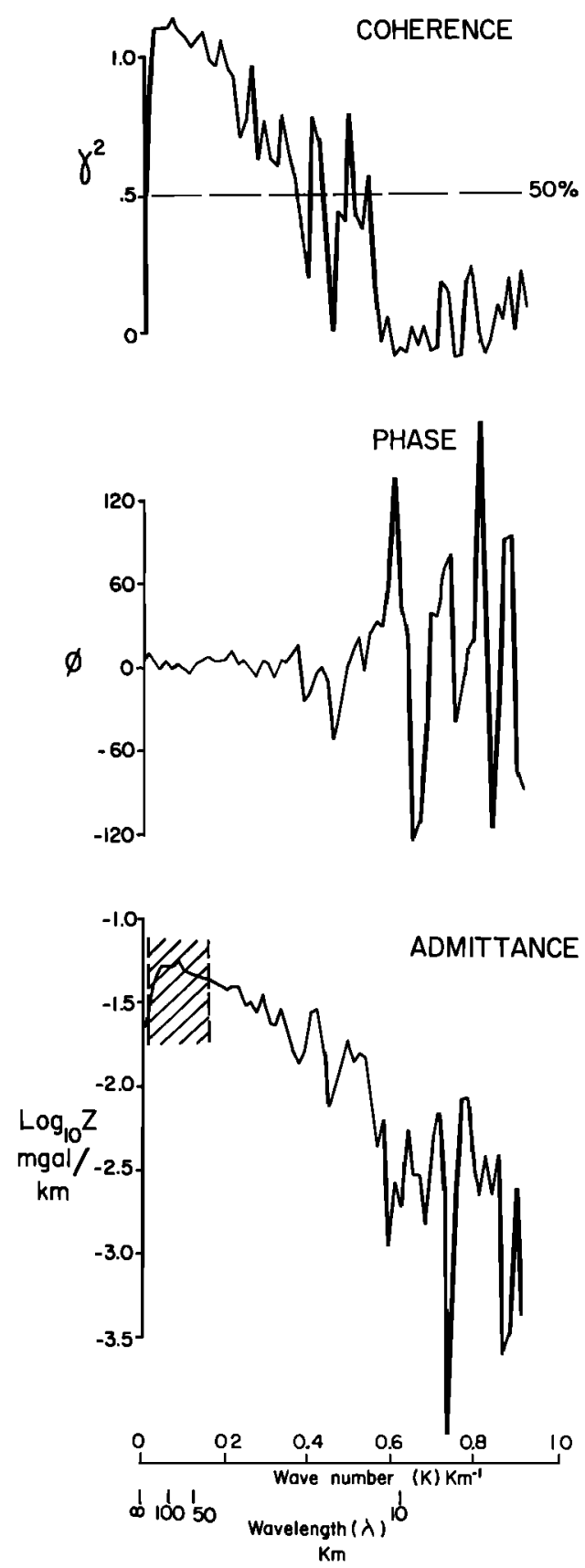

Fig. 11. The coherence, the phase in degrees and the $\log _{10}$ of the admittance generated from the free air gravily anomaly and bathymetry profiles in Figure 6. The shaded region box is shown in more detail in Figure 12.

nave and Dominh [1984], which assume two dimensionality (13-23 km). Inspection of Figure 1 shows that the northern part of the ridge is more or less continuous along the strike of the ridge, which may account for the agreement. The agreement is poor, however, between the results of this study (27-42 $\mathrm{km}$ ) and those of Cazenave and Dominh [1984] for the southern part of the ridge $(10-19 \mathrm{~km})$. Figure 1 shows that the southern part of the ridge consists of isolated peaks superimposed on a more or less continuous "edifice." Cazenave and Dominh [1984] used SYNBAPS, which shows that the southern part of the ridge comprises a number of isolated peaks.

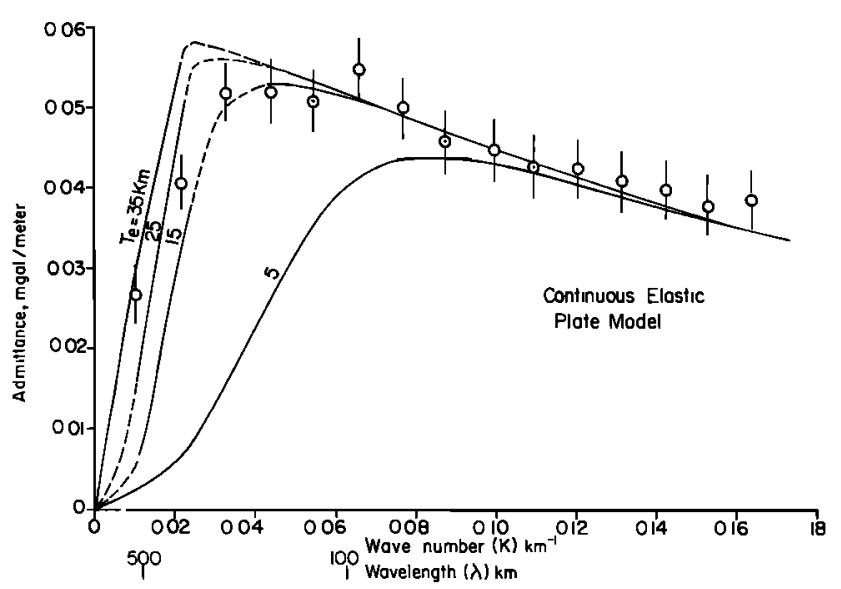

Fig. 12. "Observed" admittance values (open circles) generated from the free air gravity anomaly and bathymetry profiles in Figure 6 compared to "calculated" values based on equations (A16) and (9) of McKenzie and Bowin [1976] and Watts [1978] with the parameters summarized in Table 4 (solid curves). The calculated values have been determined for different values of $T_{e}$, the effective elastic thickness of oceanic lithosphere, and assume two dimensionality of the topography.

We, on the other hand, assumed the ridge is more or less continuous over long distances (i.e., two dimensional) so that, as Figure 17 shows, a high value of $T_{e}$ is preferred.

We conclude from Table 5 that while $T_{e}$ is uncertain for the southern part of the ridge, $T_{e}$ is in the range $10-20 \mathrm{~km}$ at the northern part of the ridge. This suggests, using the results of Watts [1978], that the Louisville Ridge formed, at least in part, in an off-ridge setting. Assuming that $T_{e}$ is determined by the depth to the $450^{\circ} \mathrm{C}$ oceanic isotherm, the results in Table 5 indicate that the northern part of the ridge formed on 12-55 $\mathrm{Ma}$ oceanic lithosphere. The tectonic setting of the southern part of the ridge is unclear. Table 5 suggests that it is likely that this part of the ridge also formed off-ridge. Whether the southern part of the ridge was nearer or farther from the ridge crest than the northern part at the time of its emplacement cannot, however, be determined from the presently available gravity and bathymetry data.

\section{Eltanin Fracture Zone System}

Existing bathymetric charts [Mammerickx et al., 1974] show that the smooth trend of the Louisville Ridge continues into the Eltanın Fracture Zone system. This system comprises two major fracture zones, named [Molnar et al., 1975; Weissel et al., 1977] after B. C. Heezen and M. Tharp. The Heezen

TABLE 4 Summary of Parameters Assumed in Model Calculations in Figure 12

\begin{tabular}{ll}
\hline \multicolumn{1}{c}{ Parameter } & \multicolumn{1}{c}{ Value } \\
\hline Youngs modulus & $1 \times 10^{12} \mathrm{dyn} \mathrm{cm}^{-2}$ \\
Average densily of topography & $2.5 \mathrm{~g} \mathrm{~cm}^{-3}$ \\
Average density of crust & $2.8 \mathrm{~g} \mathrm{~cm}^{-3}$ \\
Average density of mantle & $3.4 \mathrm{~g} \mathrm{~cm}^{-3}$ \\
Poisson's ratio & 0.25 \\
Average thickness of oceanic & $5.0 \mathrm{~km}$ \\
crust before flexure & \\
Mean water depth & $3.5 \mathrm{~km}$ \\
\hline
\end{tabular}



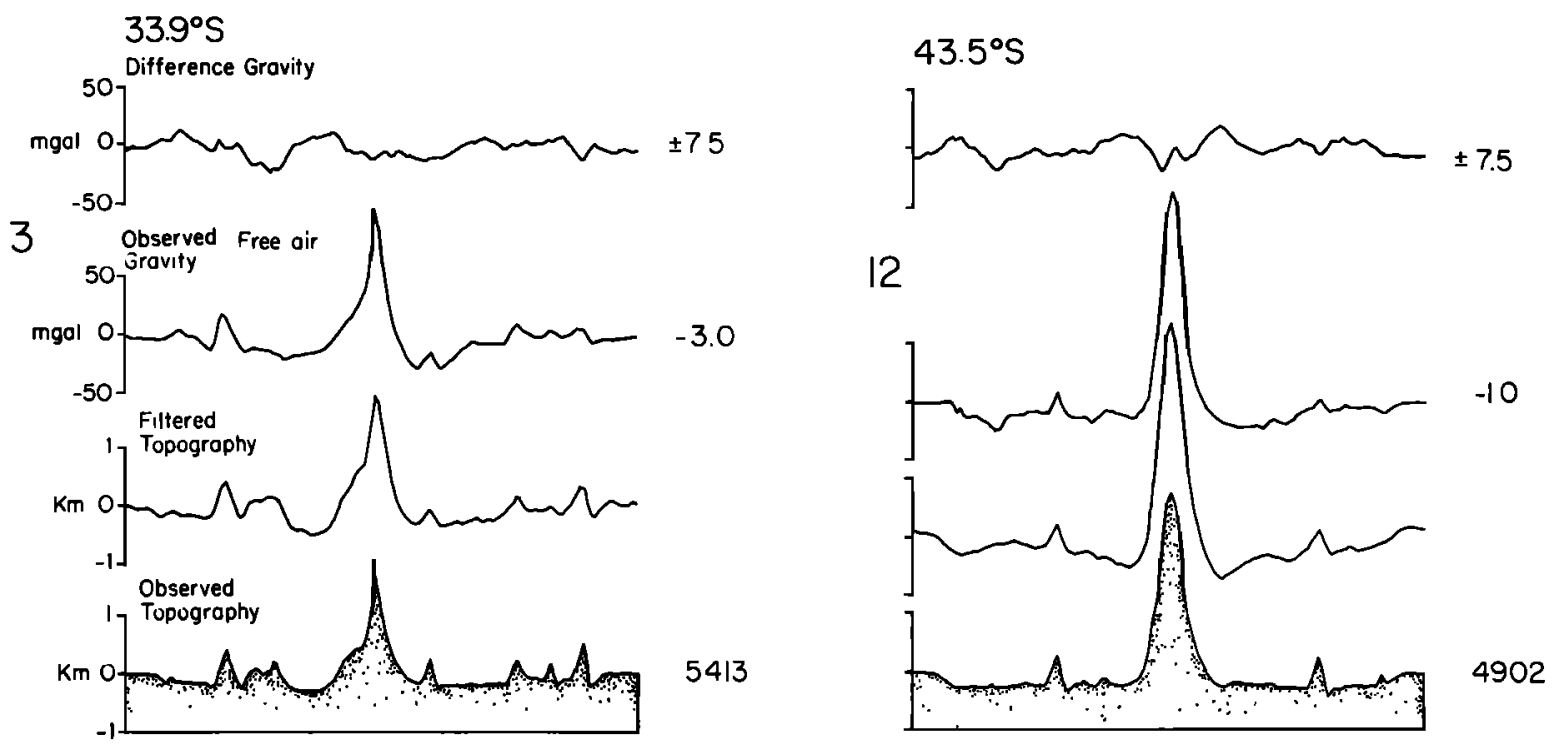

$36.3^{\circ} \mathrm{S}$
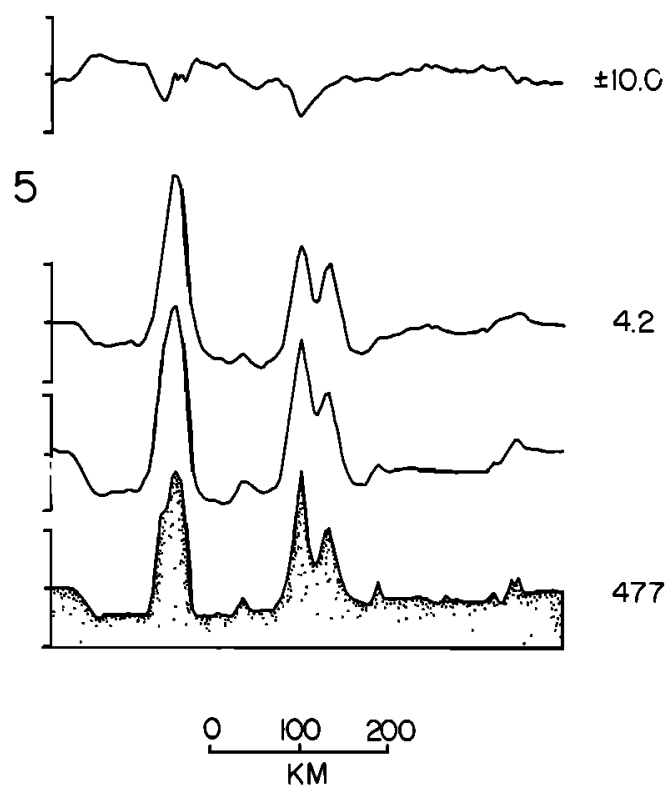

Fig. 13. Difference gravity, "observed" free air gravity, filtered topography and "observed" topography for profile 3 of the northern Louisville Ridge (latitude $33.9^{\circ} \mathrm{S}$ ), profile 5 of the central portion $\left(36.3^{\circ} \mathrm{S}\right.$ ), and profile 12 of the southern portion $\left(43.5^{\circ} \mathrm{S}\right)$. The observed gravity and bathymetry profiles correspond to the profiles in Figure 6 with their mean value and trend removed. The mean values are indicated to the right of each profile. The filtered topography profiles were obtained by inverse Fourier transforming the product of the admittance (Figure 11) and Fourier transform of the bathymetry. The difference gravity is the difference between observed gravity and filtered topography and represents that part of the observed gravity that cannot be accounted for by the admittance in Figure 11. The number to the right of the difference gravity is the rms value in milliGals.

and Tharp fracture zones are recognized in bathymetric and magnetic data [Molnar et al., 1975] by offsets in the East Pacific Rise crest, linear magnetic anomalies, and regionally averaged bathymetric contours. The existence of the fracture zones can also be inferred from geoid anomaly "steps" and geoid slope (deflection of the vertical) peaks. On the basis of all available bathymetric, magnetic, and geoid data the offset across the system is in a right-lateral sense and is about 1000 $\mathrm{km}$.

Molnar et al. [1975] mapped a more or less continuous sequence of magnetic anomalies in the vicinity of the Eltanin Fracture Zone system, extending from the rise crest to anomaly $32(72 \mathrm{Ma})$. They noted that at anomaly 26 time $(60 \mathrm{Ma})$ there was an abrupt change in spreading rate on the rise crest 


\section{Profile 2}
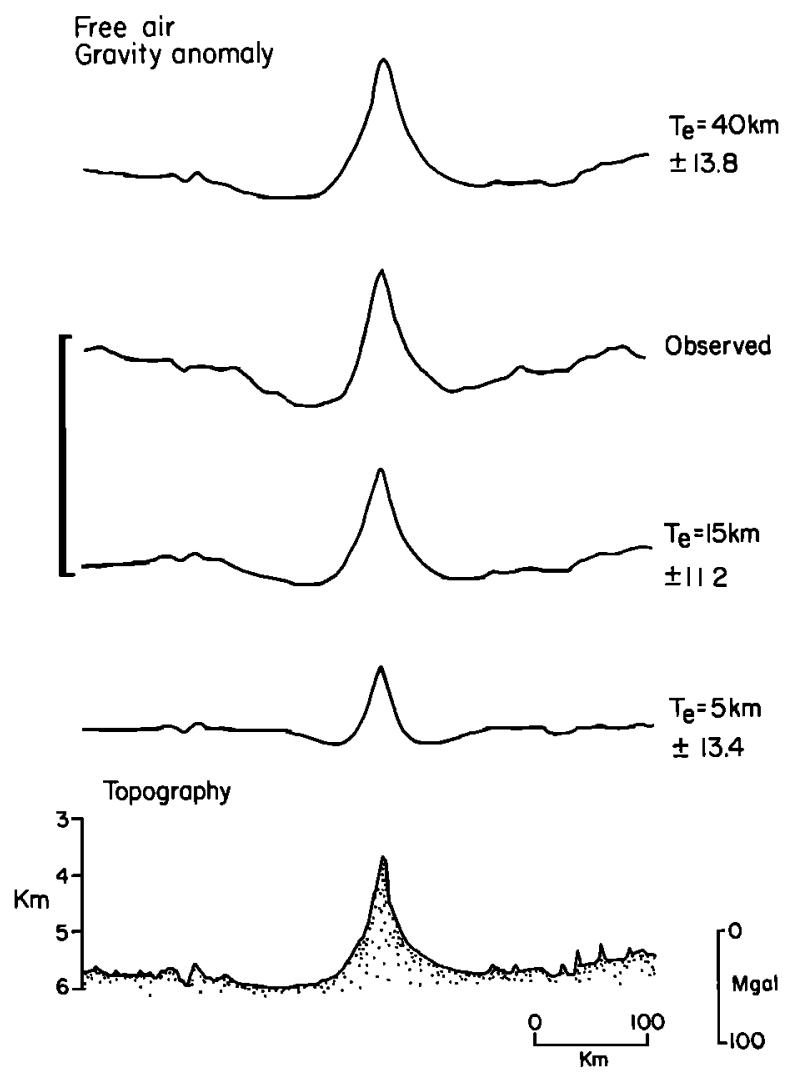

Fig. 14. "Observed" free air gravity and bathymetry profile 2 compared to theoretical profiles generated for $T_{e}=5,15$, and $40 \mathrm{~km}$. The number to the right of each theoretical profile is the rms difference between observed and calculated values. Note that the smallest rms value is for $T_{e}=15 \mathrm{~km}$.

from about $4.5 \mathrm{~cm} / \mathrm{yr}$ prior to it to about $1.5-2.5 \mathrm{~cm} / \mathrm{yr}$ after it. Molnar et al. [1975] noted, in addition, that magnetic anomaly trends differed either side of the fracture zone system (being more northerly in trend to the north than the south) and that during present to anomaly 5 time and anomaly 31-21 time spreading rates were somewhat higher to the north of the system than to the south.

Weissel et al. [1977] recognized anomaly 34 as the older identifiable magnetic anomaly in the southwest Pacific and were the first to document that spreading rates were significantly different either side of the Eltanin Fracture Zone system. They noted that during anomaly 30-34 time, rates were up to a factor of 2 higher north of the fracture zone system than to the south.

Neither Molnar et al. [1975] nor Weissel et al. [1977] were able to identify magnetic anomalies older than anomaly 32 and 34 , respectively. They concluded, therefore, that the age of the crust underlying the Louisville Ridge was Cretaceous based on extrapolation of spreading rates either side of the Eltanin Fracture Zone.

In order to understand better the relationship between the Louisville Ridge and the Eltanin Fracture Zone, we examined in more detail the tectonic fabric of the seafloor in the vicinity of the intersection of these features. Figure 18 shows that anomalies 33 and 34 continue almost uninterrupted across the ridge. Anomalies 31 and 32, on the other hand, are clearly offset across the Tharp and Heezen fracture zones, respectively.

The magnetic anomaly identifications in Figure 18 are verified in Figure 19 by using a magnetic anomaly "block" model. Apparently, during anomaly 27 to 34 time, spreading rates were about $7.0-9.0 \mathrm{~cm} / \mathrm{yr}$ north of the Eltanin Fracture Zone system and about $4.0 \mathrm{~cm} / \mathrm{yr}$ to the south. By about anomaly 27 time, however, the rates were similar at about $3.0 \mathrm{~cm} / \mathrm{yr}$.

One of the most important conclusions that can be drawn from Figure 18 is that at anomaly 34 time $(84 \mathrm{Ma})$, when New Zealand broke away from Antarctica, there was essentially no offset at the location where the Eltanin Fracture Zone system was later to develop. This is clearly seen in Figure 20, which shows that anomalies 33 and 34 can be identified in each of the three "compartments" adjacent to the Heezen and Tharp fracture zones. Although some minor $(<100 \mathrm{~km})$ offsets do occur, there are no major offsets that could be attributed to a

\section{Profile 11}
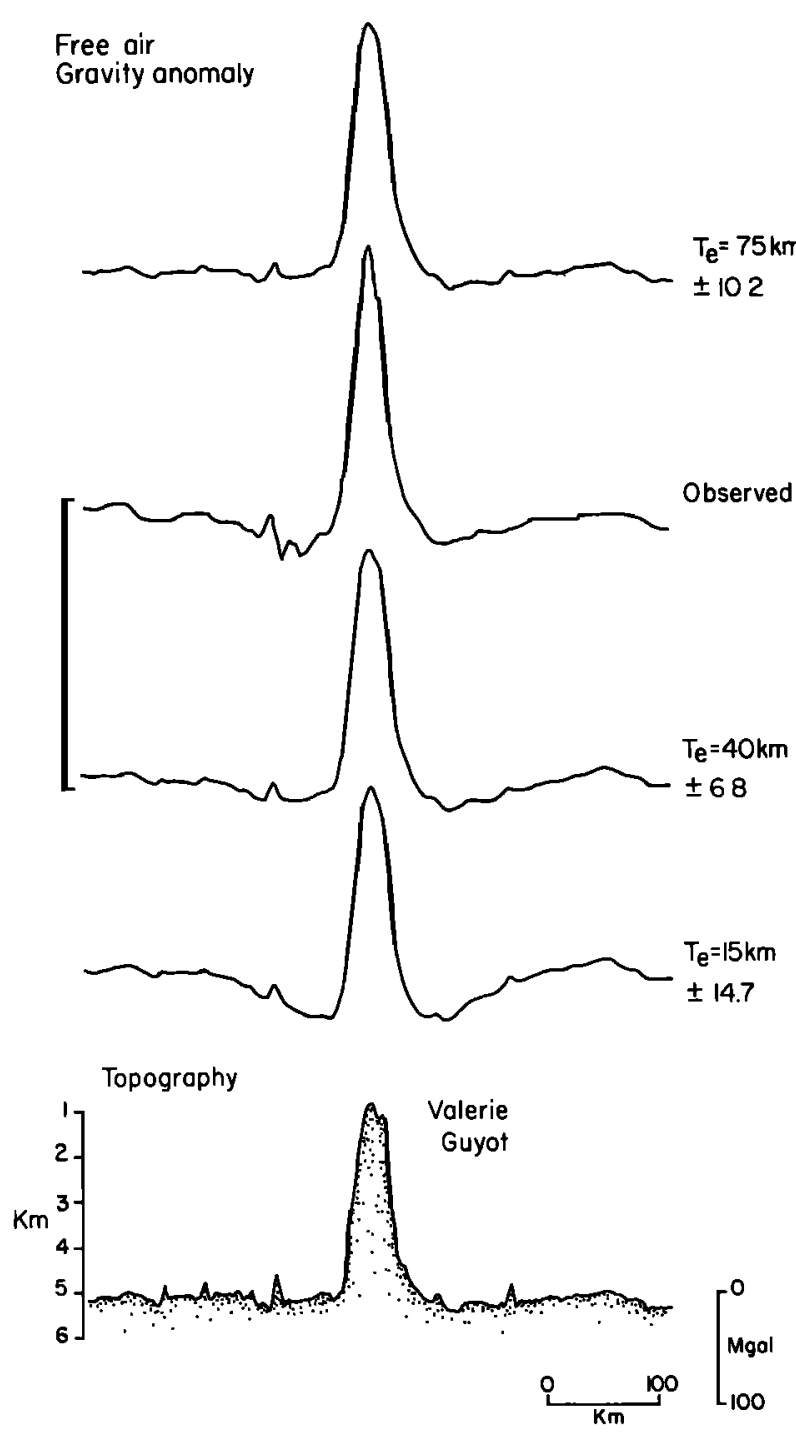

Fig. 15. "Observed" free air gravity and bathymetry profile 11 compared to theoretical profiles generated for $T_{e}=15,40$, and $75 \mathrm{~km}$. Symbols and annotations as in Figure 12. 


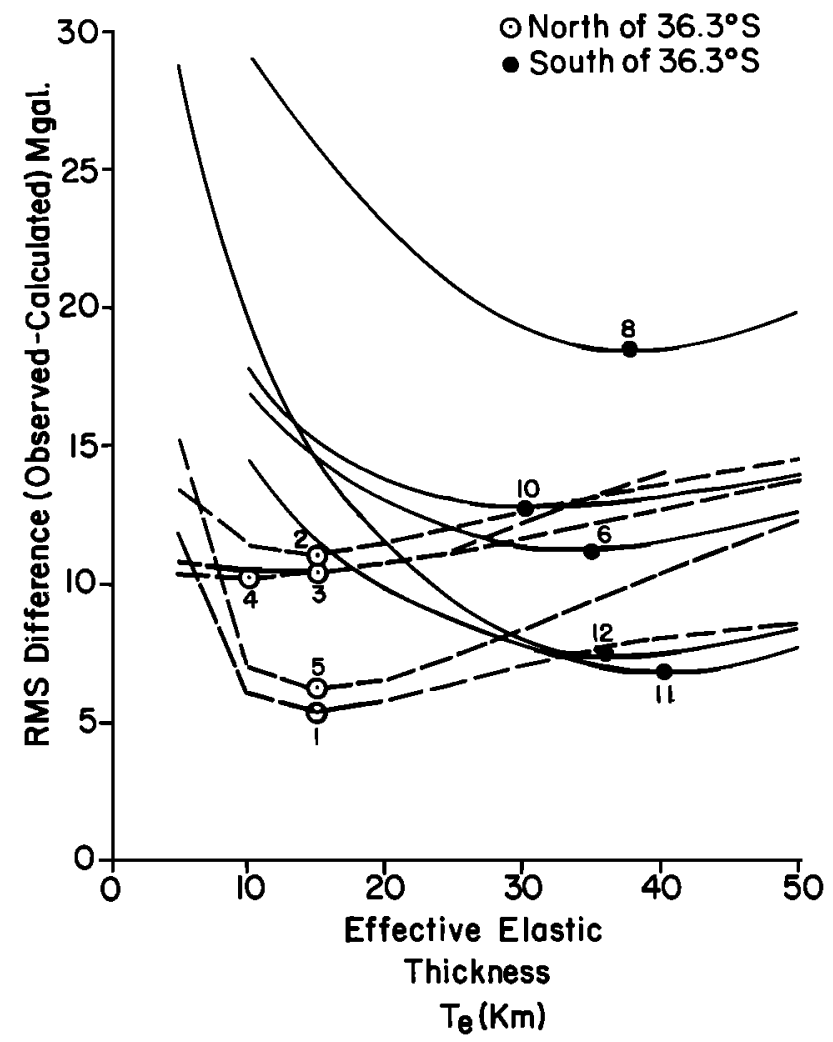

Fig. 16. Plot of rms difference between observed and calculated gravity anomaly profiles against $T_{e}$ for profiles 1-12 along the Louisville Ridge. Profiles 7 and 9 have not been plotted because they did not show any well-developed minimum. Note that the northern portion of the ridge is associated with generally low $T_{e}$ values $(10<$ $T_{e}<20 \mathrm{~km}$ ), while the southern portion is associated with high values $\left(27.5<T_{e}<42.5 \mathrm{~km}\right)$. This result, which is at variance with that of Cazenave and Dominh [1984], is discussed more fully in the text.
TABLE 5. Comparison of Estimates of $T_{e}$ Determined From Figure 16 With Those of Cazenave and Dominh [1984]

\begin{tabular}{|c|c|c|c|}
\hline \multirow[b]{2}{*}{ Profile } & \multirow{2}{*}{$\begin{array}{c}\text { This Paper } \\
\text { (Figure 16) } \\
\text { Two Dimensional } \\
\text { km }\end{array}$} & \multicolumn{2}{|c|}{ Cazenave and Dominh [1984] } \\
\hline & & $\begin{array}{c}\text { Two Dimensional, } \\
\text { km }\end{array}$ & $\begin{array}{c}\text { Three Dimensional, } \\
\text { km }\end{array}$ \\
\hline 1 & $12.5-17.5$ & & $21.7-23.1$ \\
\hline 2 & $10.0-20.0$ & $15.0-20.0$ & $18.6-21.4$ \\
\hline 3 & $10.0-17.0$ & . & $\ldots$ \\
\hline 4 & $<15.0$ & $\ldots$ & $12.8-18.8$ \\
\hline 5 & $12.5-20.0$ & $\ldots$ & $\ldots$ \\
\hline 6 & $30.0-37.5$ & . & $\ldots$ \\
\hline 7 & $\ldots$ & $\ldots$ & \\
\hline 8 & $34.0-41.0$ & $12.0-15.0$ & $16.6-19.0$ \\
\hline 9 & & .. & \\
\hline 10 & $27.5-32.5$ & $10.0-12.0$ & $16.6-17.8$ \\
\hline 11 & $37.5-42.5$ & $12.0-15.0$ & $16.6-19.0$ \\
\hline 12 & $32.5-42.5$ & $\ldots$ & $\ldots$ \\
\hline
\end{tabular}

mid-Cretaceous Eltanin Fracture Zone. Figure 20 shows that the Louisville Ridge continues uninterrupted across these lineations, crossing almost orthogonally to their NE-SW trend.

We conclude from these observations that the Eltanin Fracture Zone did not exist at anomaly 33-34 time, and therefore it is likely that a major portion of the Louisville Ridge did not form on a preexisting fracture zone offset. We emphasize that the offset history of the Eltanin Fracture Zone can only be documented back to anomaly 33-34 time, due to the $30 \mathrm{~m} . \mathrm{y}$. magnetic Quiet Zone that precedes these reversals. However, the lack of a characteristic geoid "step" over seafloor older than anomaly 33-34 (e.g., Figure 9) together with the lack of offset at anomaly 33-34 time and subsequent offset buildup

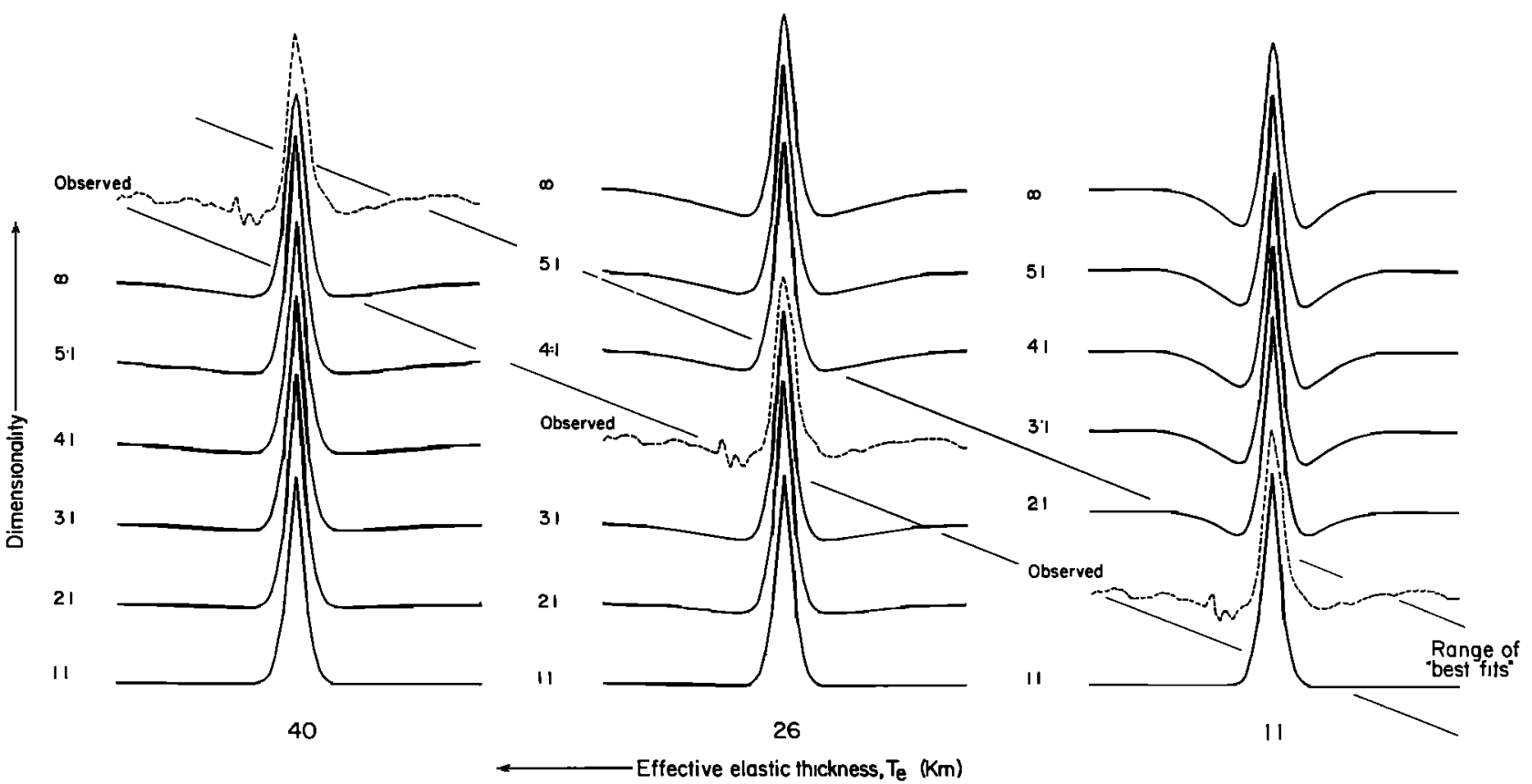

Fig. 17. Theoretical gravity anomalies based on different dimensionality and values of $T_{e}$ for a bathymetric feature with a cross section similar to that of profile 10 (Figure 6) of the Louisville Ridge. The dimensionality increases from 1:1 (circular "seamount") for the lower profiles to $\infty$ (two dimensional "volcanic ridge") for the upper profiles. A dimensionality of $3: 1$ corresponds, for example, to a feature which is approximately 3 times longer than it is wide. The value of $T_{e}$ increases in square root of $T_{e}$ units from right to left across the figure. Observed free air gravity anomaly profile 10 is shown for comparison as a dashed line. The region between the diagonal lines shows best fits based on a comparison of theoretical and observed profiles. The best fitting value of $T_{e}$ depends strongly on the dimensionality of the feature: a low value being preferred if the dimensionality is small (e.g., seamount) and a high value if the dimensionality is large (e.g., volcanic ridge). 


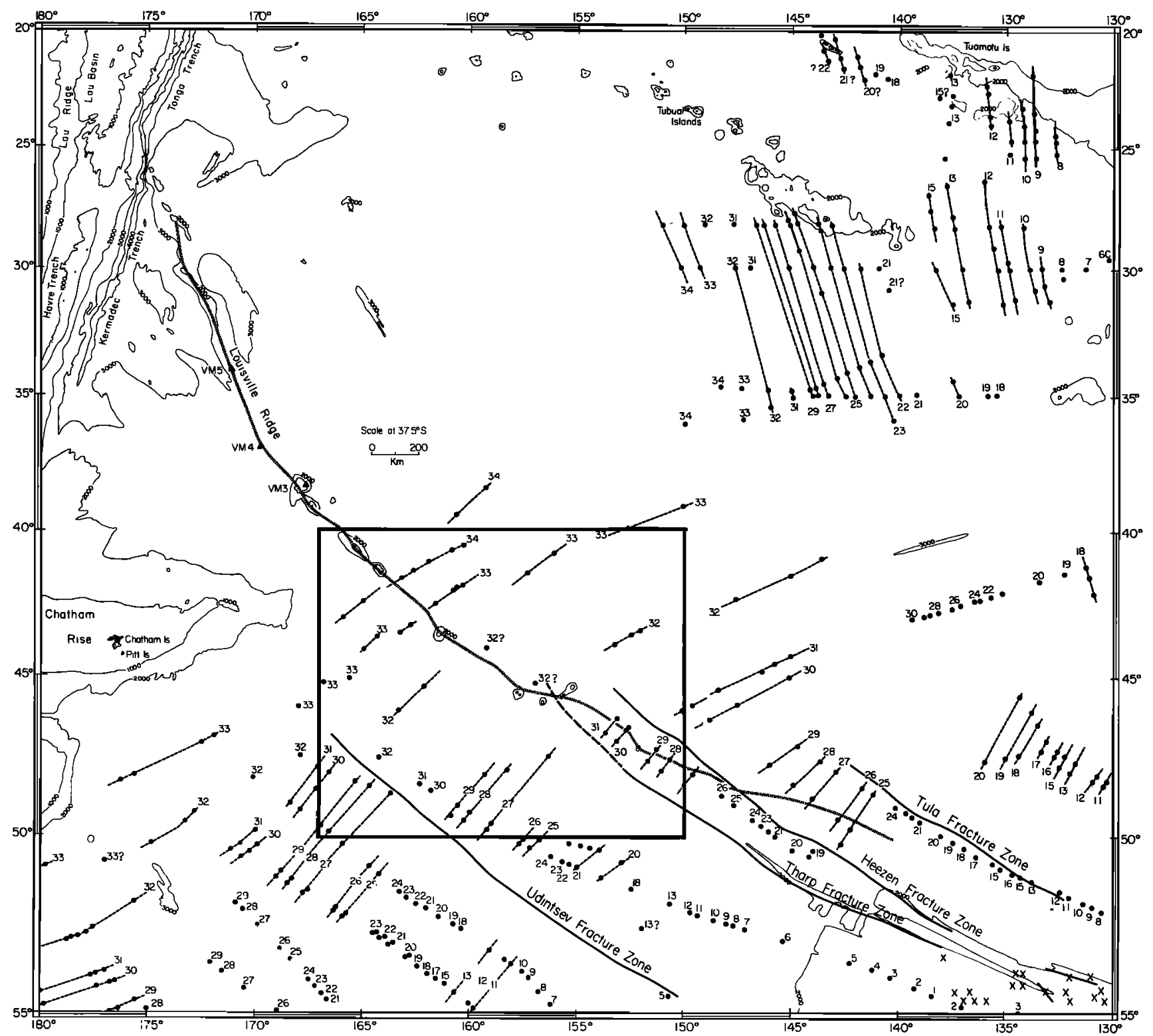

Fig. 18. Tectonic elements map of the Louisville Ridge and vicinity based on the shipboard- and satellite-derived magnetic and geoid anomaly data used in this study. The magnetic lineation identifications are based on Figure 19, and the trends of the Louisville Ridge and Heezen, Tharp (Eltanin), and Udintsez fracture zones are based on Figure 21.

argue against any significant offset of the Eltanin prior to anomaly 33-34 time.

Figures 18 and 19 show that a major portion of the offset across the Eltanin Fracture Zone system developed after anomaly 34 time, during anomaly 33-28 time. By anomaly 28 time, approximately $750 \mathrm{~km}$ of the present-day $1000 \mathrm{~km}$ of right-lateral offset had accumulated across the system. Offset continued to increase after anomaly 28 time but at a greatly reduced rate.

An outstanding question is the relationship of the Louisville Ridge to the offset portion of the Eltanin Fracture Zone system. On the basis of the magnetic data alone, it is not possible to examine the extension of the Louisville Ridge into the offset with any degree of certainty (e.g., Figure 20). Geoid data derived from Seasat altimeter radar data allow, however, the extension of the ridge into the fracture zone to be examined in more detail.
It has been shown in several studies [e.g., Watts et al., 1984; Sandwell, 1984] that seamount chains and fracture zone offsets are associated with characteristic geoid slope anomalies. In particular, the crests of seamount chains are generally marked by a nearly zero slope, while fracture zone offsets are often characterized by prominent, nearly symmetric, peaks in geoid slope. On this basis, the geoid slope map in Figure 21 can be used to trace the extent of the Louisville Ridge and Eltanin Fracture Zone system.

Figure 22 shows a detailed map of the geoid slope in the vicinity of the Louisville Ridge/Eltanin Fracture Zone intersection. The characteristic geoid slopes over seamount chains and fracture zone offisets are clearly seen in the northwest and southeast portions of the map, respectively. The symbols indicate the location of the crest of the seamount chain and the bathymetric offset in the fracture zones, as inferred from geoid data. 


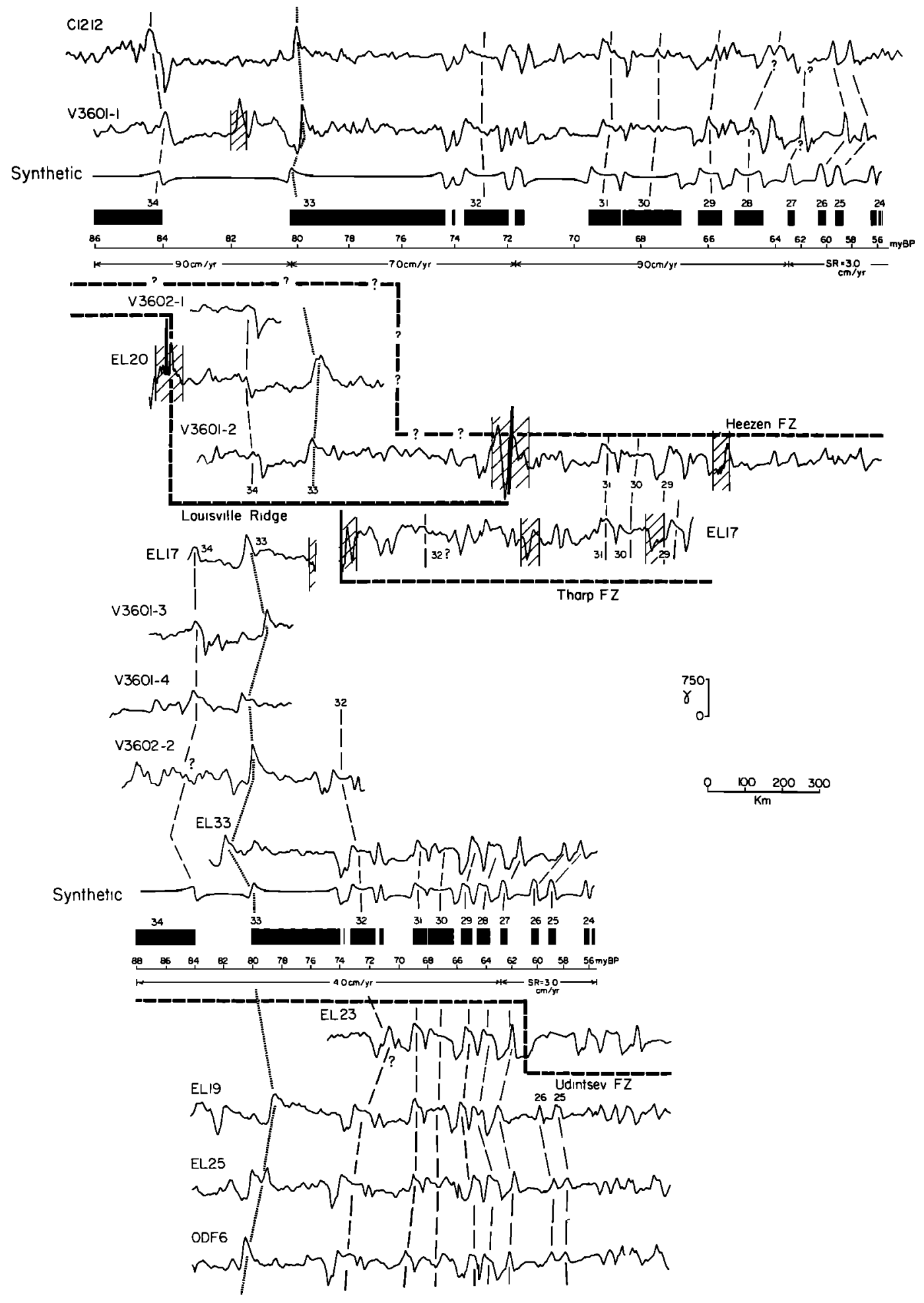

NW

SE

Fig. 19. Selected magnetic anomaly profiles in the vicinity of the Louisville Ridge compared to computed profiles. The observed profiles have been projected approximately normal to the magnetic lineation trend associated with the southwest Pacific Mid-oceanic ridge system. The computed profiles are based on the geomagnetic time scale of Berggren et al. [1985], an assumed depth to the upper surface of the magnetized layer of $5.25 \mathrm{~km}$, a uniform magnetization of $0.01 \mathrm{emu}$, a magnetic layer thickness of $0.5 \mathrm{~km}$, and the half-spreading rate shown. The solid lines schematically indicate the position of the Louisville Ridge and Heezen and Tharp (Eltanin) fracture zones. The shaded regions show the location of rough topography along individual ship tracks. 


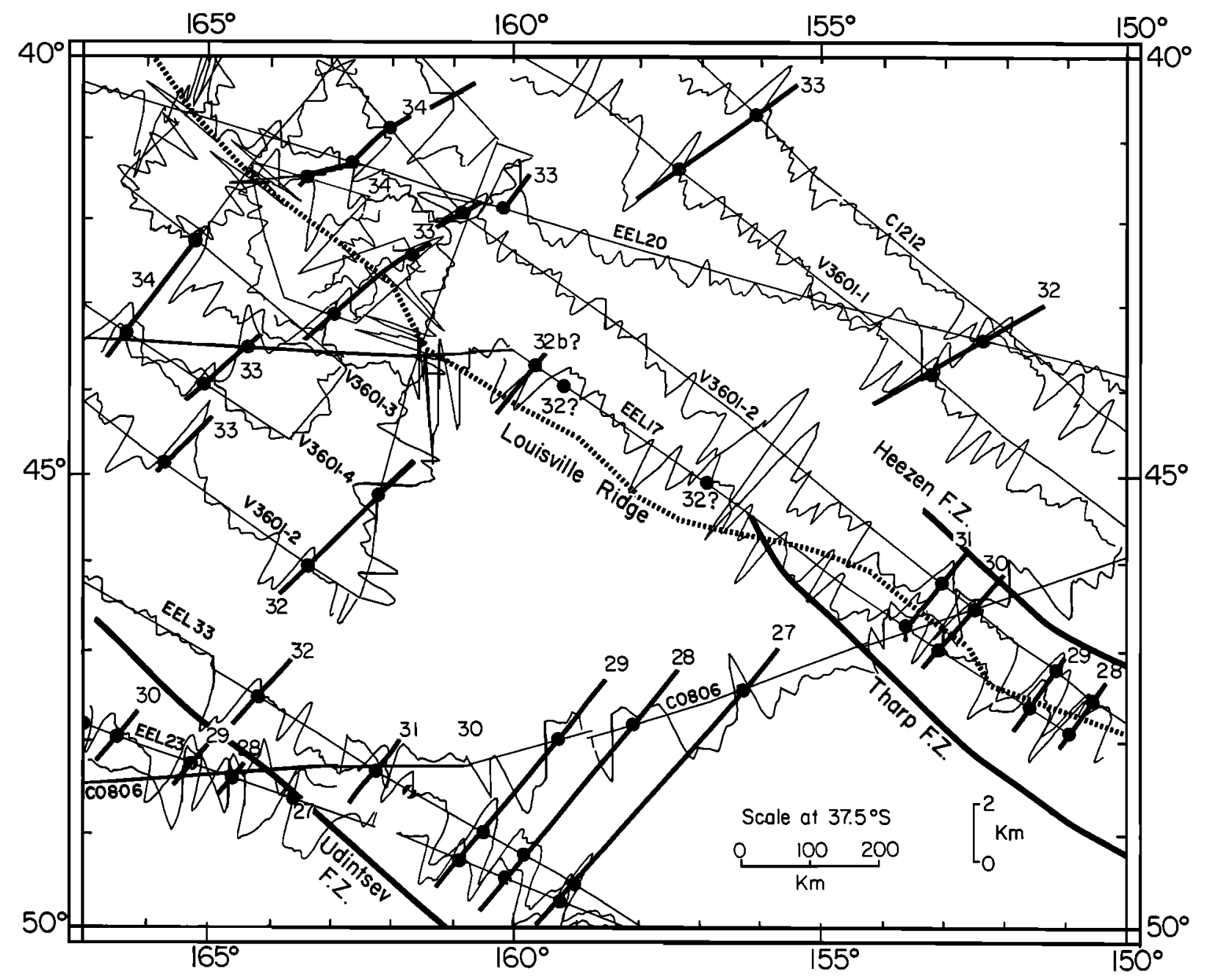

Fig. 20. Detailed map of magnetic anomaly profiles along ship tracks in the vicinity of the southern portion of the Louisville Ridge and Heezen and Tharp (Eltanin) fracture zones. Trends of the Louisville Ridge and Heezen and Tharp fracture zones are based on Figure 22. Note that the oldest well-identified magnetic anomaly in the study area is 34 and that no real offset occurs in it across the Louisville Ridge.

We compare the locations of the Louisville Ridge and Eltanin Fracture Zone deduced from Seasat data and from available bathymetric data in Figure 23. A close agreement occurs between the zero geoid slope (open circles) and the bathymetry peak on eight shipboard crossings of the ridge. The agreement is not as close, however, between the peak slopes (crosses) and bathymetric offsets on shipboard crossings of the fracture zones. While the V3601 profile shows large bathymetric variations (up to $2 \mathrm{~km}$ ) at the intersection of the geoid peak associated with the Heezen Fracture Zone, neither the C0806 nor EL17 profile shows prominent variations at the intersection of the Tharp Fracture Zone peak.

In a recent study in the Indian Ocean, Driscoll et al. [1984] reported that it is quite common for peaks in the geoid slope to be displaced by as much as $30 \mathrm{~km}$ from the bathymetric offset at fracture zones. A similar result is seen in Figure 24 for the Eltanin Fracture Zone system: the peak in the geoid slope is displaced by up to $50 \mathrm{~km}$ over the shallower, younger side of the fracture zone offset.

One of the major conclusions that can be drawn from Figure 23 is that on the basis of Seasat data, the Louisville
Ridge continues into the offset portion of the Eltanin Fracture Zone system. In particular, the ridge extends southeast of its southern most extremity based on available shipboard bathymetry data $\left(43.6^{\circ} \mathrm{S}, 161.2^{\circ} \mathrm{W}\right)$ for a distance of at least $350 \mathrm{~km}$.

Beyond a point given by $45.6^{\circ} \mathrm{S}, 156.7^{\circ} \mathrm{W}$ the extension of the ridge is less clear, although the available bathymetric and altimetric data suggests that it extends into the region of the Eltanin Fracture Zone. Bathymetric data on EL17 (Figure 23) show that the ridge continues into the compartment separatıng the Heezen and Tharp fracture zones as a number of 1solated "seamounts." The most prominent of these features are located at $45.7^{\circ} \mathrm{S}, 155.7^{\circ} \mathrm{W} ; 46.8^{\circ} \mathrm{S}, 153.2^{\circ} \mathrm{W}$; and $47.4^{\circ} \mathrm{S}$, $152.1^{\circ} \mathrm{W}$. The Seasat-derived gravity anomaly map (Plate 2 ) confirms the extension of the ridge to $47.4^{\circ} \mathrm{S}$ and shows, in addition, two well-defined gravity anomaly highs centered at $48^{\circ} \mathrm{S}, 148.7^{\circ} \mathrm{W}$ and $50^{\circ} 30^{\prime} \mathrm{S}, 139^{\circ} \mathrm{W}$. We attribute these highs to two large submarine volcanoes. We suggest, therefore, that although the ridge terminates as a continuous feature at about $45.6^{\circ} \mathrm{S}, 157^{\circ} \mathrm{W}$, it continues in the form of at least five isolated seamounts to as far south as about $50^{\circ} 30^{\prime} \mathrm{S}$.

On the basis of these results, the Scripp's Marathon ex- 


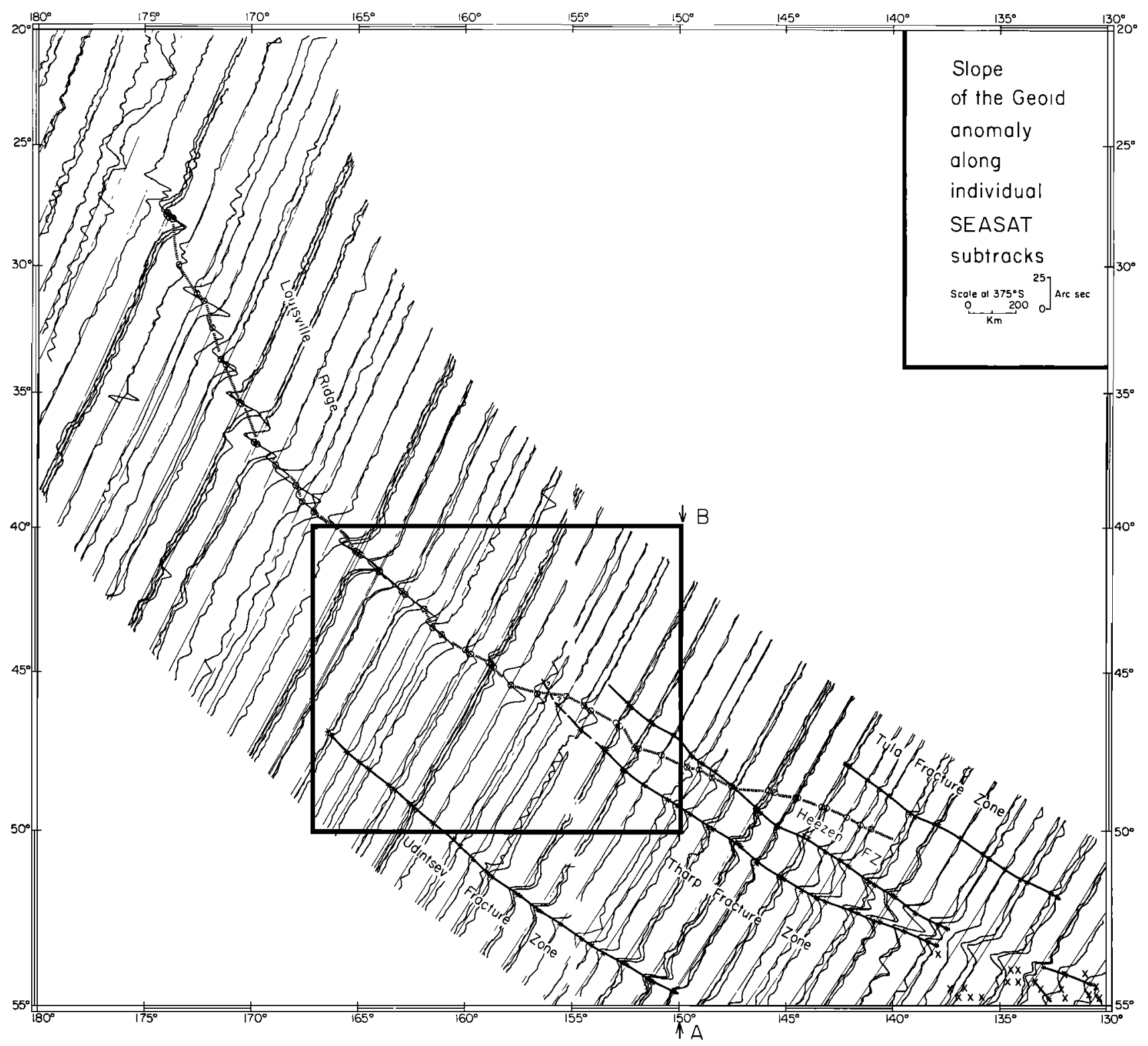

Fig. 21. The slope of the geoid anomaly along individual Seasat descending subtracks (the deflection of the vertical) in the vicinity of the Louisville Ridge. The crosses, which indicate identification of the peak in geoid slope along individual satellite subtracks, are interpreted as marking the location of major fracture zone offsets (see text for discussion). The open circles, which indicate identification of the zero geoid slope, are interpreted as marking the location of the crest of the Louisville Ridge. The heavy arrows indicate the location of geoid slope profile AB in Figure 24.

pedition extended its dredging program so as to sample the two seamounts inferred from Seasat data [Hawkins et al., 1987]. Plate 2 clearly shows that the two "Seasat" seamounts are aligned on an extension of the Louisville Ridge system. We therefore concur with Hawkins et al. [1987] that Marathon samples 6D-1 and 7D-1 (Table 5) are located on an extension of the Louisville Ridge and that the zero-age volcano at the southeast extremity of the ridge (7D-1) is the youngest sampled age along the ridge.

\section{Tectonic Evolution}

The magnetic bight $\left(37^{\circ} \mathrm{S}, 145^{\circ} \mathrm{W}\right)$ indicates that during the Late Cretaceous a three-plate system existed in the South Pa- cific, the Pacific plate being one of them (Figure 18). By mapping lineated magnetic anomaly sequences in the north and central Pacific, Larson and Chase [1972] concluded that the other two plates in the system were the Farallon and Phoenix plates. Most of the Phoenix plate has since been subducted beneath South America and what remains is shown in Figure 25 as the Aluk plate. Only fragments of the Farallon plate remain (Cocos, Rivera, Gorda, Juan de Fuca, and Nazca).

As we noted previously, the Eltanin Fracture Zone system is the largest single tectonic element in the southwest Pacific Molnar et al. [1975] suggested that anomalies 32 and younger south of the fracture zone were generated at the Pacific/ Antarctic plate boundary, whereas anomalies to the north 


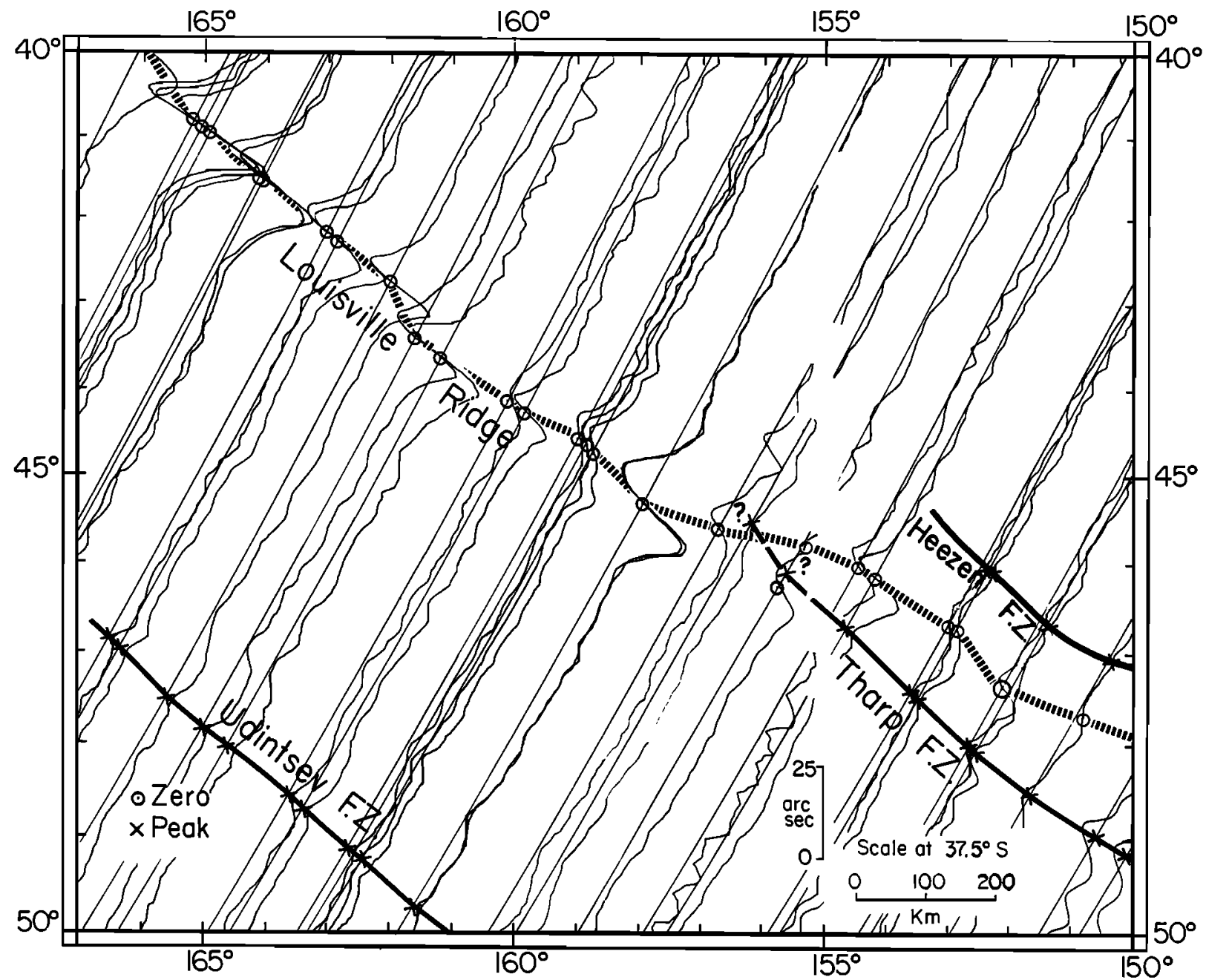

Fig. 22. Detailed map of geoid slopes along Seasat subtracks in the vicinity of the southern portion of the Louisville Ridge and Heezen and Tharp (Eltanin) fracture zones. The symbols and identifications are as in Figure 19.

formed at the Pacific/Farallon plate boundary. According to Molnar et al. [1975] it was not until about anomaly 32 time that the Phoenix plate in Larson and Chase's [1972] threeplate scheme corresponded to the Antarctic plate. Due to lack of data, however, Molnar et al. [1975] were not able to locate the actual Pacific, Antarctic, and Farallon Triple Junction.

Weissel et al. [1977] pointed out that the measured rate for the Pacific/Farallon boundary $(9-10 \mathrm{~cm} / \mathrm{yr})$ could not be explained by the vector sum of rates for the Pacific Antarctic and Antarctic/Farallon boundaries. In order to explain the discrepancy, an additional plate is required which they referred to as the Aluk plate. Weissel et al. [1977] proposed that prior to anomaly 26 time (which corresponded to an abrupt change of spreading rate in the southwest Pacific) there were therefore two triple junctions: one involving the Pacific, Antarctic, and Aluk plates and the other the Pacific, Farallon, and Aluk plates.

The plate tectonic model in Figure 25 illustrates the proposed manner in which plate boundaries evolved in the vicinity of the Eltanin Fracture Zone. Prior to anomaly 34 time (Figure 25a), the Pacific-Aluk ridge crest was spreading at about $10 \mathrm{~cm} / \mathrm{yr}$. Much of the Phoenix plate was consumed at a subduction zone extending from north of New Zealand/Cha- tham rise along the West Antarctica margin. At anomaly 34 time (Figure $25 b$ ) the ridge migrated to a point opposite a hypothetical trench-trench transform. At that point the ridge jumped across New Zealand, and New Zealand began to separate from Antarctica. This ridge jump closed off subduction north of New Zealand/Chatham rise and set up a Pacific, Antarctica, and Aluk triple junction. The triple junction was located at the developing Heezen Fracture Zone between anomaly 34 and 33 time, as evidenced by slow spreading rates of $4.0 \mathrm{~cm} / \mathrm{yr}$ on the Pacific-Antarctica ridge south of the Tharp Fracture Zone and in the compartment between Heezen and Tharp and by rates of $9.0 \mathrm{~cm} / \mathrm{yr}$ on the Pacific-Aluk ridge north of Heezen (Figure 19). During anomaly 33-31 time (Figure $25 c$ ) the triple junction may have moved temporarily to the southwest thereby creating the complex magnetic anomaly patterns in the compartment between the Heezen and Tharp fracture zones. By anomaly 31 time the triple junction had reestablished itself at the Heezen Fracture Zone where it persisted until about anomaly 27 time. After anomaly 27 time the triple junction migrated to the northeast (Figure $25 e$ ) so that all three fracture zone compartments became part of the Pacific-Antarctica plate boundary until at least anomaly 26 time. Between anomaly 27 and 18 time a major plate 


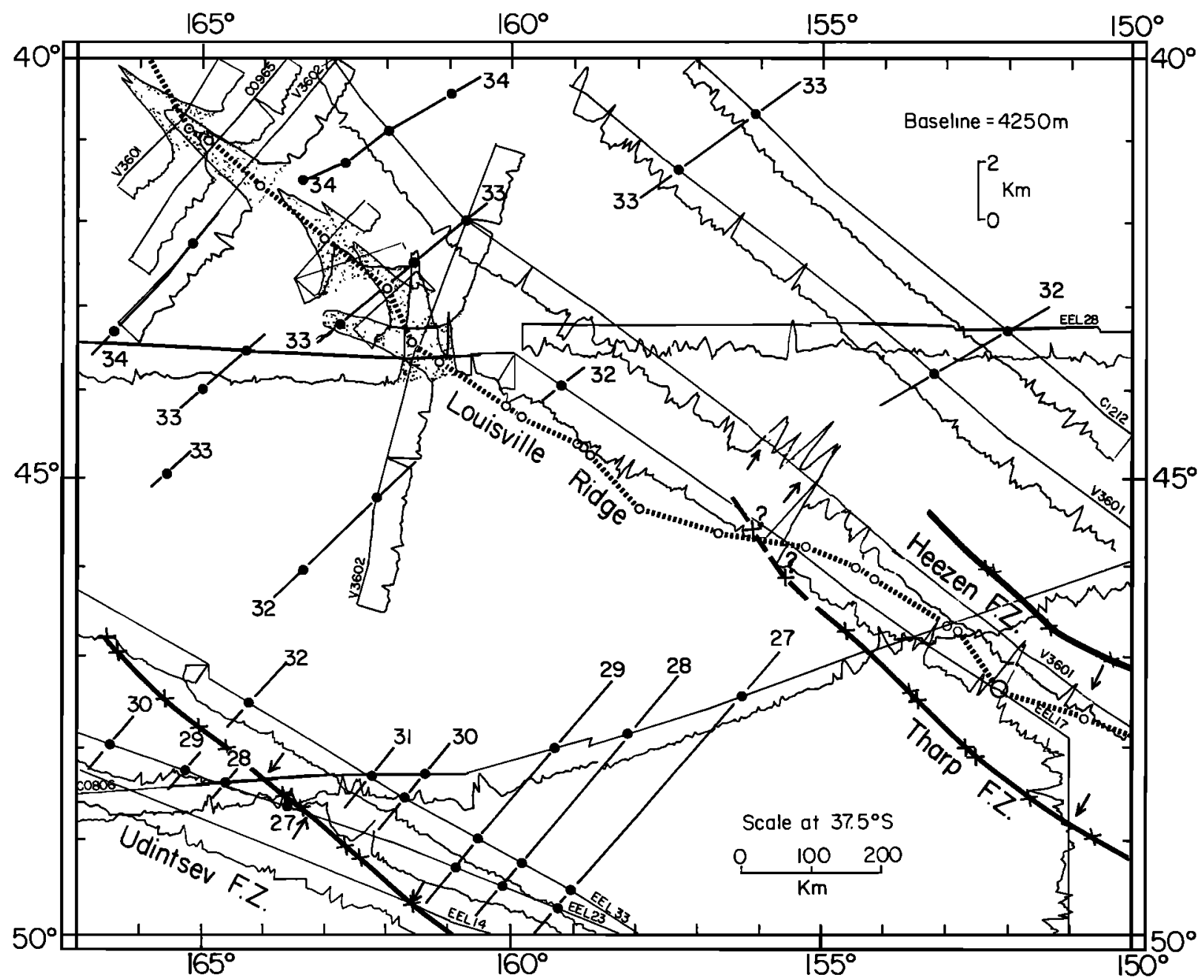

Fig. 23. Comparison of predicted trends of the crest of the Louisville Ridge (open circles) and Heezen and Tharp fracture zones (crosses) based on Seasat satellite radar altimeter data to bathymetry data along available ship tracks in the detailed map area shown in Figures 20 and 22. Note that where ship tracks cross the Louisville Ridge, there is an excellent correspondence between zero geoid slope (open circles) and the crest of the ridge. The correspondence is not as close for the Heezen and Tharp fracture zones, in part because of lack of shipboard data. The peak geoid slope (cross) appears to be located systematically to the south of the Tharp Fracture Zone ridge on EL17 and C0806 profiles by about $20 \mathrm{~km}$. At the Heezen Fracture Zone, however, the peak slope correlates with a region of rough, irregular topography on V3601.

reorganization occurred when a large fragment of the Pacific plate was broken off and added to the Antarctic plate [Cande et al., 1982]. Although there were still two triple junctions in the South Pacific, these now involved the Pacific, Antarctica, and Farallon plates and the Antarctic, Farallon, and Aluk plates.

The radiometric ages reported in this paper suggest that the Louisville Ridge was forming during this major reorganization. Flexural studies, however, suggest that the ridge was emplaced in an off-ridge setting rather than on or near a ridge crest. Thus, even though the ridge appears continuous with the Heezen and Tharp fracture zone trends, it was emplaced in the interior of the Pacific some distance (several hundred kilometers) from either of the two triple junctions.

\section{Discussion}

One of the most striking features of the Pacific Ocean basin is the large number of relatively long linear chains of oceanic islands and seamounts. Most volcanic chains trend generally WNW-ESW and were apparently formed over stationary hot spots during the past 43 m.y. Another group of chains trend approximately NNW-SSE and can be explained by the same mechanism.

The hot spot hypothesis is readily tested since it predicts that ages should progressively increase along a seamount chain. Clague and Jarrard [1973] reviewed the available age data from Pacific islands and concluded that while many of the WNW-ESW chains such as the Hawaiian, Kodiak-Bowie, Marquesas, and Guadalupe showed an age progression, a number of the NNW-SSE chains such as Emperor, MarshalGilbert, and Line islands did not. R. A. Duncan and D. A. Clague (unpublished manuscript, 1987) reviewed the recent age data and concluded that age progression also could be discerned along the Emperior and Line islands chains, thereby supporting the hypothesis.

An alternative to the hot spot hypothesis is the propagating crack or fracture hypothesis. This hypothesis predicts that 


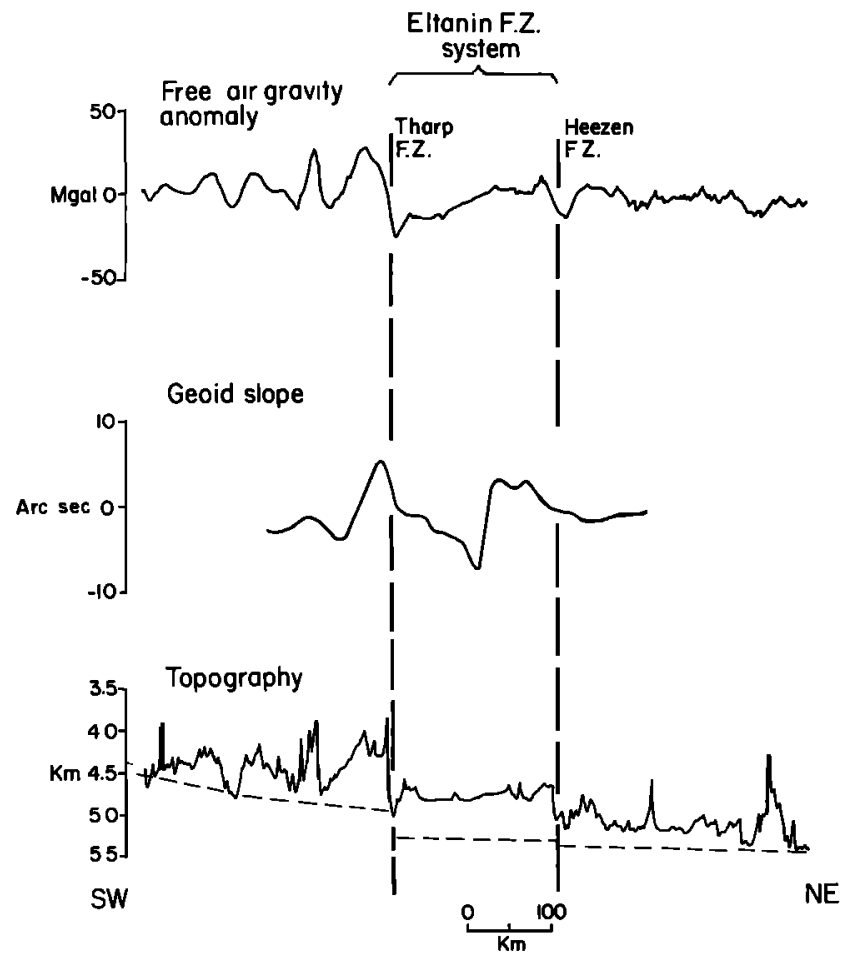

Fig. 24. Free air gravity anomaly, geoid slope and topography profile of the Heezen and Tharp (Eltanin) fracture zones at longitude $150^{\circ} \mathrm{E}$. The gravity anomaly and topography profile is based on CSS Hudson cruise 68-5. The geoid slope was interpolated from measurements along nearby Seasat satellite radar altimeter tracks. The dashed lines on the topography profile indicate theoretical depths based on the identification of magnetic anomalies in Figures 18 and 19 and the cooling plate model of Parsons and Sclater [1977]. The peak in the geoid slope is displaced $10-35 \mathrm{~km}$ over the younger, upthrown side of the fracture zones as inferred from the shipboard topography profile. The zero free air gravity anomaly is similarly displaced but by a smaller amount of $5-10 \mathrm{~km}$. The profiles have been projected approximately normal to the local trend of the Eltanin Fracture Zone system (azimuth $=032^{\circ}$ ).

fractures in the lithosphere, due to preexisting lines of weakness or plate-edge effects, control linear volcanic chains. In contrast to the hot spot hypothesis, this hypothesis predicts that ages will be generally similar along the length of a chain. With the possible exception of the Easter Island/Sala $y$ Gomez-San Felix/San Ambrosio chain [Bonatti and Harrison, 1976], no linear chains in the Pacific have yet been satisfactorily explained by this hypothesis.

Recently, a third hypothesis has been advanced [Okal and Cazenave, 1985] in which it is proposed that the hot spot and fracture mechanisms interact to control the location of seamount chains. According to this hypothesis, the Oeno-Ducie volcanic line is a surface expression of the Tuamotu hot spot, but its trace was deviated by about $15^{\circ}$ due to the effects of a young active fracture zone offsetting the East Pacific Rise crest. This hypothesis suggests that hot spot and fracture zone systems may have some influence on the kinematics of each other.

In this section, we examine the hot spot origin for the Louisville Ridge in the light of the new bathymetric, gravity, geoid, and age data.

One of the predictions of the hot spot hypothesis is that ages should progressively increase from southeast to the northwest along the ridge. Our studies, together with those of
Hawkins et al. [1987] would place the location of the hot spot near the zero-age volcano, MTHN 7D-1 (Table 3), at the southern extremity of the ridge (Plate 2). Figure 26 shows that when the ages in Table 3 are plotted as a function of position from MTHN 7D-1, a clear progression can be seen along the ridge. If the Louisville hot spot is fixed in an absolute motion frame, then Figure 26 indicates that velocity of the Pacific plate over the Louisville "hot spot" was about $6.4 \mathrm{~cm} / \mathrm{yr}$ between $43 \mathrm{Ma}$ and the present and about $6.0 \mathrm{~cm} / \mathrm{yr}$ prior to 43 Ma.

Although the age progression exhibited by the Louisville Ridge is therefore compatible with the fixed hot spot hypothesis, the published poles of rotation for Pacific plate motion are not able to adequately account for the detailed trend variations of the ridge (e.g., Plate 2). We attribute this difficulty to the previous paucity of age and bathymetric data from the southern Pacific. We therefore have fit age and bathymetric data from the Louisville Ridge using a modified set of stage rotation poles for Pacific plate motion during the Tertiary.

A similar modified set of poles has been used by Lonsdale [this issue], who show it is consistent with Sea Beam data collected along the crest of the ridge. In addition, we show that both the Louisville Ridge and the Hawaiian-Emperor seamount chain can be fit by the same modified poles, implying that the two hot spots have, in fact, been stationary with respect to one another since $65 \mathrm{Ma}$.

The ages, together with gravity and magnetic evidence, allow us to speculate on the tectonic setting of the Louisville Ridge. We conclude that the present-day ridge formed after the major offset developed on the Eltanin transform fault from 60 to $80 \mathrm{Ma}$. From 60 to $28 \mathrm{Ma}$ the Louisville Ridge developed more or less continuously on oceanic crust with little or no offset. Flexural studies (Table 5) indicate this ridge segment formed on 12-55 Ma oceanic crust. By $28 \mathrm{Ma}$, the distance between hot spot and ridge crest had decreased sufficiently for the ridge to be emplaced on an offset portion of the old fracture zone. Existing flexural studies cannot accurately constrain the tectonic setting of seamount emplacement, but the results in Table 5 are in accord with the Louisville ridge segment formed during 28-12 Ma being emplaced on oceanic crust at least as old as $25 \mathrm{Ma}$. Since about $20 \mathrm{Ma}$, however, volcanism waned, so that volcano building was limited to a few isolated seamounts. These seamounts extend into the compartment between the Heezen and Tharp fracture zones and appear to cross the Heezen. Figure 26 shows that the isolated seamounts generally align along the Louisville hot spot trace.

According to the modified set of rotation poles in Figure 26 the Louisville hot spot is presently located at about $51^{\circ} 50^{\prime} \mathrm{S}$, $139^{\circ} 30^{\prime} \mathrm{W}, 1500 \mathrm{~km}$ from the East Pacific Rise crest and close to a "Iossil" offset of the Heezen Fracture Zone. Inspection of residual depth anomaly (observed minus expected depths based on thermal age) maps of the southwest Pacific [e.g., Menard and Dorman, 1977; Crough, 1983] show a depth anomaly high of about $600 \mathrm{~m}$ centered in the vicinity of the hot spot. The magnitude of this depth anomaly is in accord with the results of this study, which suggest unusually shallow depths along the southern part of the ridge (Figure 2) which continue to at least the latitude of the Hudson crossing of the Eltanin Fracture Zone system (Figure 24). As Plate 2 shows, the Louisville hot spot appears to have a depth anomaly high similar to other midplate hot spots in the Pacific. We caution, however, that there are presently too little magnetic and bathymetric data available for this region for us to determine 

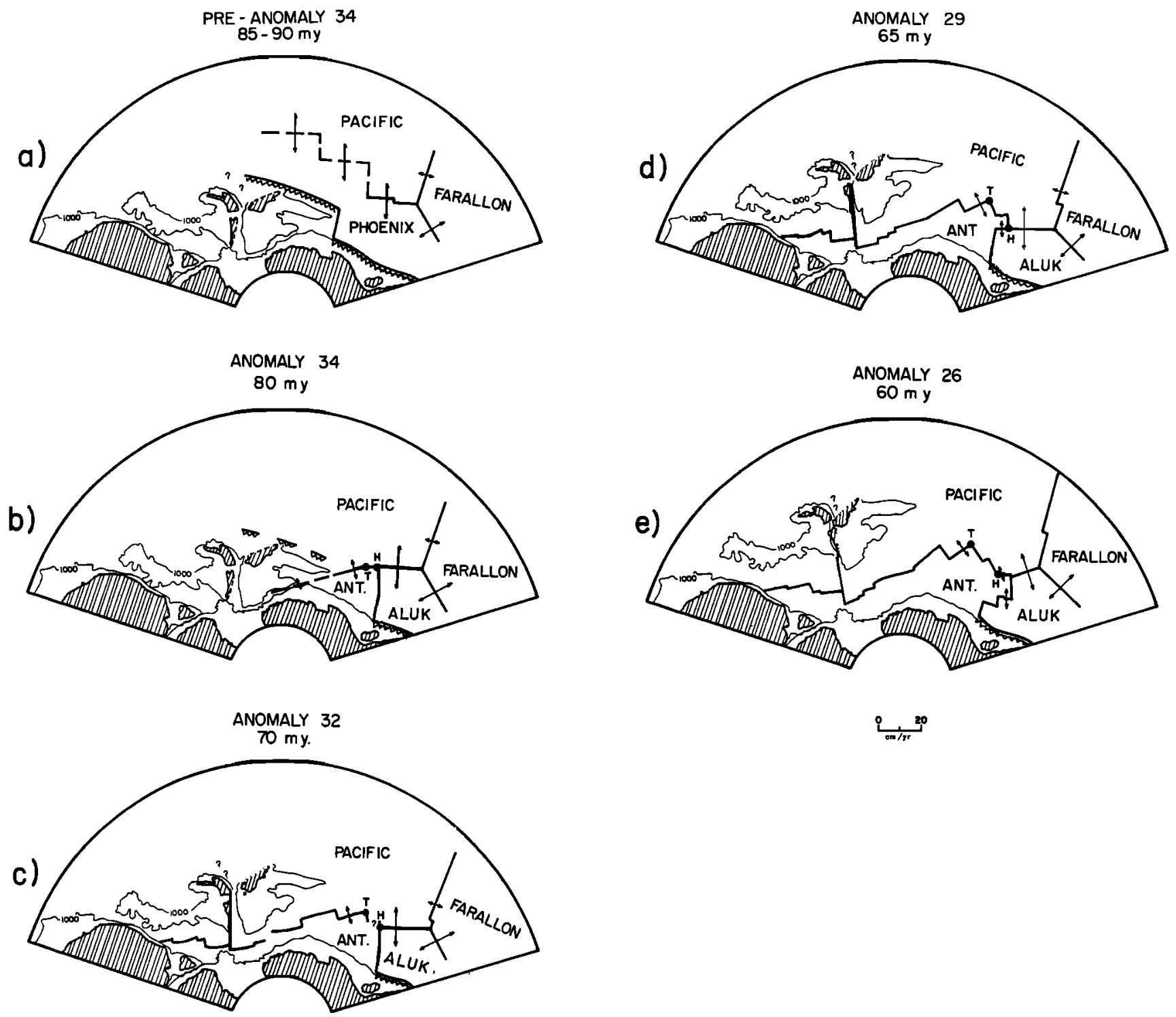

Fig. 25. Configuration of the continental fragments (shaded) and major plate boundaries in the southwest Pacific region during pre-anomaly $34(80-90 \mathrm{Ma})$ to anomaly $26(60 \mathrm{Ma})$ time. The configuration assumes that there has been no relative movement between East and West Antarctica and that Antarctica has remained fixed in its present geographic position. All rotations were performed with respect to Antarctica using finite rotation poles compiled from magnetic lineation patterns in the Tasman basin and the Pacific basin south of New Zealand by Weissel et al. [1977]. The lengths of divergent arrows at divergent plate boundaries indicate spreading rates. Heavy dots labeled " $T$," " $H$," and " $U$ " locate the Tharp, Heezen, and Udintsez fracture zones, respectively. The " $\mathrm{V}$ " indicates the approximate location of volcanic activity along the Louisville Ridge assuming that the ridge at $27.5^{\circ} \mathrm{S}$ is about $60 \mathrm{~m}$.y. old (Figure 26), that it formed on oceanic lithosphere about $35 \mathrm{~m} . y$. old (Table 5), and that it is located approximately on an extension of the Tharp Fracture Zone.

with any reliability either the bathymetry or pattern of depth anomalies associated with the Louisville hot spot.

The continuity in smooth trend of the Louisville Ridge and Eltanin Fracture Zone suggests that some relationship exists between them. Magnatism on the ridge does not appear, however, to have been "captured" by the developing Eltanin Fracture Zone. A majority of the ridge did not form on an offset. Moreover, soon after the magmatism reached an offset portion of the fracture zone, it waned. Thus contrary to the predictions of Okal and Cazenave [1985], the development of the ridge appears to have been little influenced by the thermal and mechanical regime of the Eltanin Fracture Zone.
The continuity of the ridge and fracture zone therefore remains enigmatic. It may be a coincidence: a consequence of a large amount of hot spot activity in the Pacific, a center of which just happens to line up with one of the Pacific's largest fracture zone systems. Alternately, there is some fundamental process linking the kinematics of the ridge and fracture zone with each other. Clearly, more data will be required to solve this problem in the future. Of particular interest will be geological and geophysical data from the southern extremity of the ridge, in the vicinity of the Louisville hot spot. This region, we believe, holds the key to our understanding of this problem as well as other aspects of the kinematics of the Pacific Ocean. 


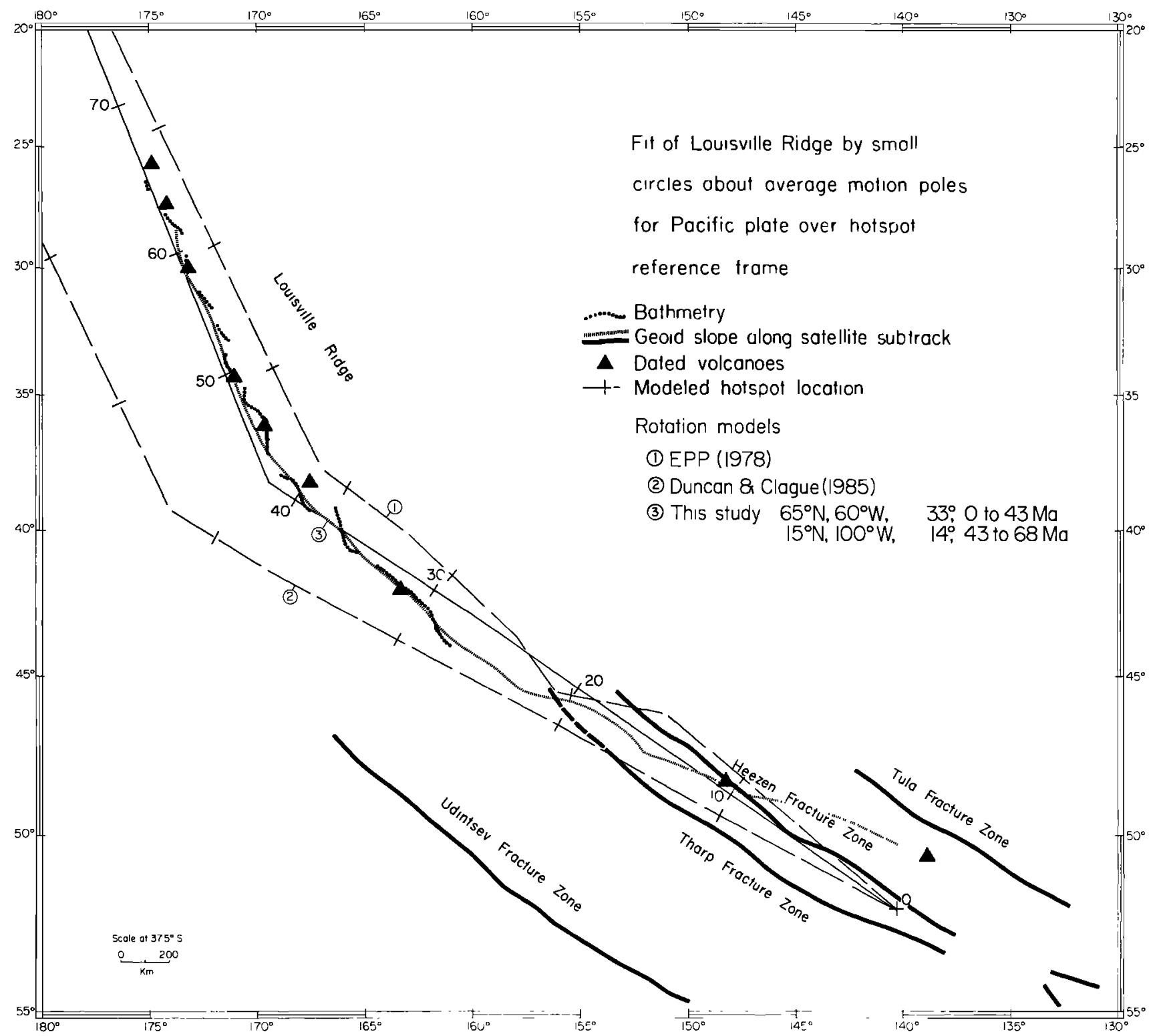

Fig. 26. Comparison of trend of Louisville Ridge based on bathymetry (heavy dots) and geoid slopes (hatched line) to computed trends based on average motion poles for the Pacific plate over the hot spot reference frame. The best fit to the observed trend is for the modified stage poles discussed in this paper. The zero age indicates the probably position of the Louisville hot spot. According to our data, the hot spot is presently located on or close to the Heezen Fracture Zone. We caution, however, that the fracture zone trends in the figure are based on geoid slope peaks which, as shown in Figure 24, may not correspond to the actual bathymetric offset.

\begin{abstract}
Acknowledgments. We are grateful to the late B. C. Heezen for his contributions to the intial planning of the R/V Vema cruise to the Louisville Ridge and Eltanin Fracture Zone. The collection of the large amount of data reported in this paper would not have been possible without the help of the officers, scientific staff, and crew of R/V Vema. We would like to thank J. Hawkins (SIO) and F. J. Davey (Department of Scientific and Industrial Research) for providing us access to unpublished bathymetric data in the region prior to the cruise, J. Bodine for his help at sea, and J. Glasser and W. Smith for their help in postcruise data analysis. This work was supported by National Science Foundation grant OCE 7725993 (A.B.W., J.K.W., R.L.L.), Office of Naval Research contract TO-0132, Scope "I" (A.B.W.), and Scope "QQ" (J.K.W.). Lamont-Doherty Geological Observatory contribution $\mathbf{4 2 5 5}$.
\end{abstract}

\section{REFERENCES}

Berggren, W. A., D. V. Kent, J. J. Flinn, and J. A. Van Couvering, Cenozoic geochronology, Geol. Soc. Am. Bull., 96, 1407-1418, 1985.
Bonatti, E., and C. G. A. Harrison, Hot lines in the Earth's mantle, Nature, 263, 402-404, 1976.

Born, G. H., M. A. Richards, and G. W. Rosborough, An empirical determination of the effects of sea state bias on Seasat altimetry, $J$. Geophys. Res., 87, 3221-3226, 1982.

Cande. S. C., E. M. Herron, and B. R. Hall, The early Cenozoic tectonic history of the southeast Pacific, Earth Planet. Sci. Lett., 57, 63-74, 1982.

Cazenave, A., and $\mathbf{K}$. Dominh, Geoid heights over the Lousville Ridge (South Pacific), J. Geophys. Res., 89, 11,171-11,179, 1984.

Chase, T. E., S. M. Smith, D. A. Newhouse, W. L. Crocker, M. Schoenbechler, L. Hydock, and U. Ritter, Track charts of SIO bathymetric data and track charts of SIO magnetic data in the Pacific Ocean, IMR TR-25 Sea Grant Publ. 7, Scripps Inst. of Oceanogr., LaJolla, Calif., 1972.

Christoffel, D. A., and R. K. H. Falconer, Marine magnetic measurements in the southwest Pacific Ocean and the identification of new tectonic features, in Antarctic Oceanology II: The Australian-New 
Zealand Sector, Antarct. Res. Ser., vol. 19, edited by D. E. Hayes, pp. 197-209, AGU, Washington D. C., 1972.

Clague, D. A., and G. B. Dalrymple, Cretaceous $\mathrm{K} / \mathrm{Ar}$ age of volcanic rocks from the Musicians seamounts and the Hawainan Ridge, Geophys. Res. Lett., 2, 305-308, 1975.

Clague, D. A., and R. D. Jarrard, Tertiary Pacific plate motion deduced from the Hawaiian-Emperor chain, Geol. Soc. Am. Bull., 84, $1135-1154,1973$.

Crough, S. T., Hot spot swells, Annu. Rev. Earth Planet. Sci., II $165-193,1983$.

Dalrymple, G. B., and D. A. Clague, Age of the Hawallan-Emperor bend, Earth Planet. Sci. Lett., 50, 260-274, 1976.

Dalrymple, G. B., M. A. Lanphere, and D. A. Clague, Conventional and ${ }^{40} \mathrm{Ar}-{ }^{39} \mathrm{Ar}$ ages of volcanic rocks from Ojin (site 430 ), Nintoku (site 432), and Suiko (site 433) seamounts and the chronology of volcanic propagation along the Hawaiian-Emperor chain, Initial Rep. Deep Sea Drill. Proj., 55, 659-676, 1981.

Davey, F. J., and A. B. Watts, Free-air gravity field of the New Zealand region, Geol. Soc. Am. Spec. Map Chart Ser., MC-48, 1983.

Dorman, L. M., and B. T. R. Lew1s, Experimental isostasy, 1, Theory of the determination of the Earth's isostatic response to a concentrated load, J. Geophys. Res., 75, 3357-3365, 1970.

Driscoll, M. L., R. L. Fisher, and B. Parsons, A comparison of Seasat altımetry and bathymetry over the southwest Indian Ridge, Eos Trans. $A G U, 65,1104,1984$.

Duncan, R. A., A captured ssland chain in the Coast Range of Oregon and Washington, J. Geophys. Res., 87, 10,827-10,837, 1982.

Duncan, R. A., Age progressive volcanism in the New England Seamounts and the opening of the central Atlantic Ocean, J. Geophys. Res., 89, 9980-9990, 1984.

Epp, D., Age and tectonic relationships among volcanic chains on the Pacific plate, Ph.D. thesis, Univ. of Hawaii at Manoa, Honolulu, 1978.

Ewing, J., M. Ewing, T. Aitken, and W. J. Ludwig, North Pacific sediment layers measured by seismic profiling, in The Crust and Upper Mantle of the Pacific Area, Geophys. Monogr. Ser., vol. 12, edited by L. Knopoff, C. L. Drake, and P. J. Hart, pp. 147-173, AGU, Washington, D. C., 1968.

Giardini, D., and J. H. Woodhouse, Horizontal shear flow in the mantle beneath the Tonga Arc, Nature, 319, 551-555, 1986.

Hawkins, J., P. Lonsdale, and R. Batiza, Petrologic evolution of the Louisville "Ridge", Eos Trans. $A G U, 66,405,1985$.

Hawkins, J., P. Lonsdale, and R. Batiza, Petrologic evolution of the Louisville seamount chain, in Seamounts, Islands, and Atolls, Geophys. Monogr. Ser., vol. 43, edited by B. H. Keating, P. Fryer, R. Batiza, and G. W. Boehlert, pp. 235-254, AGU, Washington, D. C., 1987.

Haxby, W. F., G. D. Karner, J. L. LaBrecque, and J. K. Weissel, Digital images of combined oceanic and continental data sets and their use in tectonic studies, Eos Trans. AGU, 64, 995-1004, 1983.

Hayes, D. E., and M. Ewing, The Louisville Ridge-A possible extension of the Eltanin Fracture Zone, in The Use of Artificial Satellites for Geodesy, Antarctic Res. Ser., vol. 15, edited by S. W. Henrikson, A. Mancini, and B. H. Chovitz, pp. 223-228, AGU, Washington, D. C., 1971.

Honnorez, J., The aging of the oceanic crust at low temperature, in The Sea, vol. 7, edited by C. Emilianı, pp. 525-587, WileyInterscience, New York, 1981.

Larson, R. L., and C. G. Chase, Late Mesozoic evolution of the western Pacific Ocean, Geol. Soc. Am. Bull., 83, 3627-3644, 1972.

Lonsdale, P., Geography and history of the Louisville hotspot chain in the southwest Pacific, J. Geophys. Res., this issue.

Lorell, J., M. E. Parke, and J. F. Scott, Geophysical data record (GDR) users handbook, 90 pp., Jet Propul, Lab., Pasadena, Calif. 1980.

Mammerickx, J., S. M. Smith, I. L. Taylor, and T. E. Chase, Bathymetry of the South Pacific, IMR TR-45 Sea Grant Publ. 12, Scripps Inst. of Oceanogr., La Jolla, Calif., 1974.

Marsh, J. G., C. J. Koblinsky, A. Brenner, B. Beckley, and T. Martin, Global mean sea-surface computation based upon a combination of Seasat and GEOS-3 satellite altimeter data, paper presented at
Geopotential Research Misson (GRM) Science Conference, Univ of M., College Park, Oct. 1984

McKenzie, D., and C. Bowin, The relationshıp between bathymetry of gravity in the Atlantic Ocean, J. Geophys. Res., 81, 1903-1915, 1976

McKenzie, D., A. B. Watts, B. Parsons, and M. Roufosse, Planform of mantle convection beneath the Pacific Ocean, Nature, 288, 442-446, 1980.

Menard, H. W., and L. M. Dorman, Dependence of depth anomalies upon latitude and plate motion, J. Geophys. Res., 82, 5329-5335, 1977.

Molnar, P., T. Atwater, J. Mammerickx, and S. M. Smith, Magnetic anomalies, bathymetry, and the tectonic evolution of the South Pacific since Late Cretaceous, Geophys, J. R. Astron. Soc., 40, 383$420,1975$.

O'Connor, J. M., and R. A. Duncan, Radiometric age determinations for volcanic rocks from the Walvis Ridge and implications for plate reconstructions around the southern Atlantic Ocean, Eos Trans. $A G U, 65,1078,1984$.

Okal, E. A., and A. Cazenave, A model for the plate tectonics evolution of the east central Pacific based on Seasat investigations, Eos Trans. $A G U, 65,1076,1984$.

Ozima, M., I. Kaneoka, and S. Aramaki, K-Ar ages of submarine basalts dredged from seamounts in the western Pacific area and discussion of oceanic crust, Earth Planet. Sci Lett., 8, 237-249, 1970.

Parsons, B., and J. G. Sclater, An analysis of the variation of ocean floor bathymetry and heat flow with age, J. Geophys. Res., 82, $803-827,1977$.

Ribe, N. M., On the interpretation of frequency response functions for oceanic gravity and bathymetry, Geophys. J. R. Astron. Soc., 70, 273-294, 1982.

Sandwell, D., A detailed view of the south Pacific geoid from satellite altimetry, J. Geophys. Res., 89, 1089-1104, 1984.

Scheidegger, K. F., and D. S. Stakes, Mineralogy, chemistry and crystallization sequence of clay minerals in altered tholeitic basalts from the Peru Trench, Earth Planet. Sci. Lett., 36, 413-422, 1977.

Udintsev, G. B., et al., A new bathymetric map of the Pacific Ocean, in Oceanological Researches: Articles, no. 9, pp. 60-101, section 10 of the I.G.Y. Program, Soviet Geophysıcal Committee, Academy of Sciences USSR, Moscow, 1963.

Van Wyckhouse, R. J., Synthetic bathymetric profiling systems, technical report, U.S. Nav. Oceanogr. Office, Washington, D. C., 1973.

Watts, A. B., An analysis of isostasy in the world's oceans, 1, Hawaiian-Emperor seamount chain, J. Geophys. Res., 83, 5989$6004,1978$.

Watts, A. B., J. H. Bodine, and N. M. Ribe, Observations of flexure and the geological evolution of the Pacific ocean basin, Nature, 283, 532-537, 1980 .

Watts, A. B., K. Horai, and N. M. Ribe, On the determination of the deflection of the vertical by satellite altimetry, Mar. Geod., 8, 85$127,1984$.

Watts, A. B., J. K. Weissel, R. A. Duncan, and R. L. Larson, The origin of the Louisville Ridge and its relationship to the Eltanin Fracture Zone system, Eos Trans. $A G U, 66,360,1985 a$.

Watts, A. B., D. P. McKenzie, B. E. Parsons, and M. Roufosse, The relationship between gravity and bathymetry in the Pacific Ocean, Geophys. J. R. Astron., 83, 263-298, $1985 b$.

Weissel, J. K., D. E. Hayes, and E. M. Herron, Plate tectonic synthesis: The displacements between Australia, New Zealand, and Antarctica since the Late Cretaceous, Mar. Geol., 25, 231-277, 1977.

R. A. Duncan, College of Oceanography, Oregon State University, Corvallis, OR 97331

R. L. Larson, Graduate School of Oceanography, University of Rhode Island, Kingston, RI 02881.

A. B. Watts and J. K. Weissel, Lamont-Doherty Geological Observatory, Palisades, NY 10964

(Received June 30, 1986; revised September 22, 1987 ; accepted September 27, 1987.) 


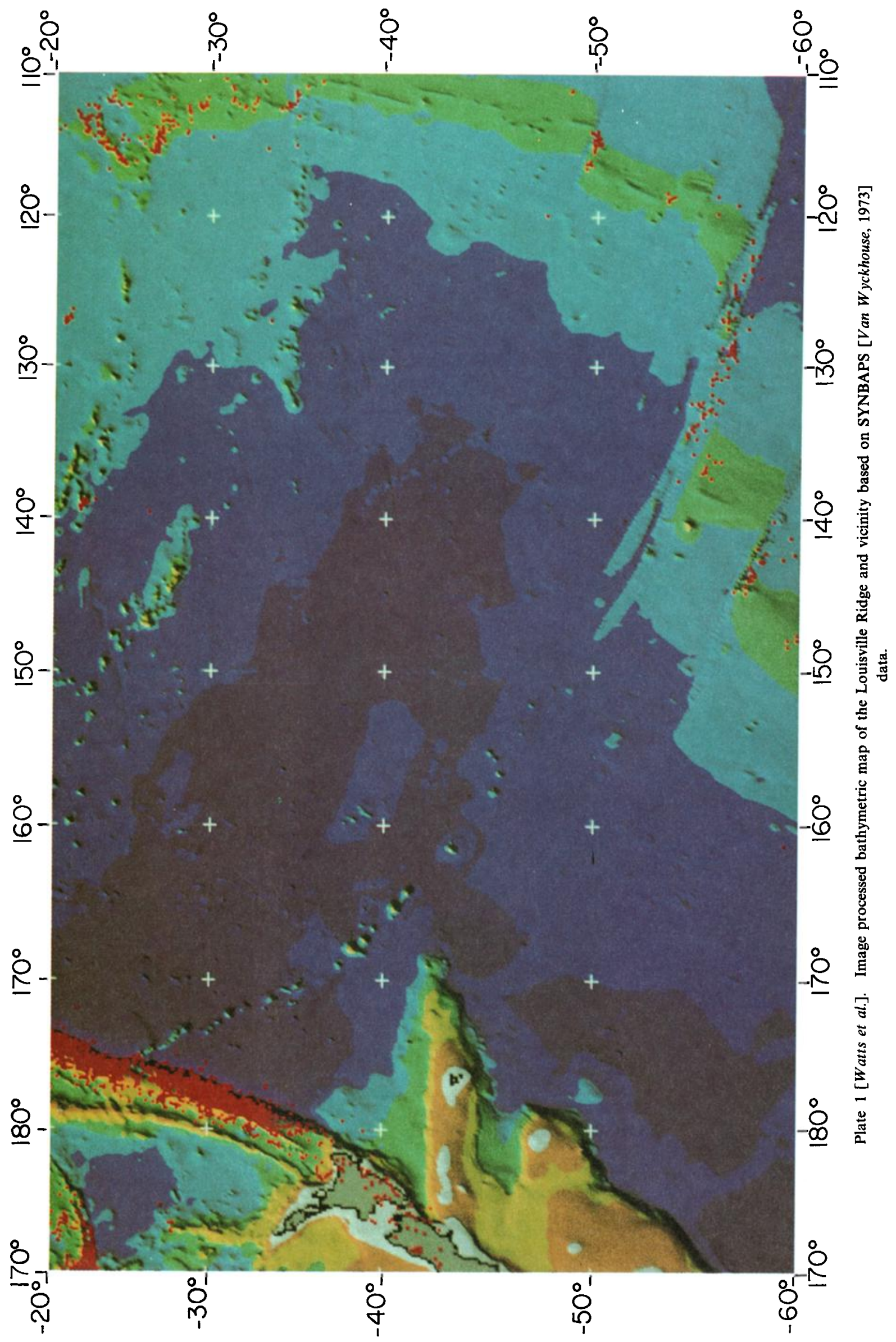




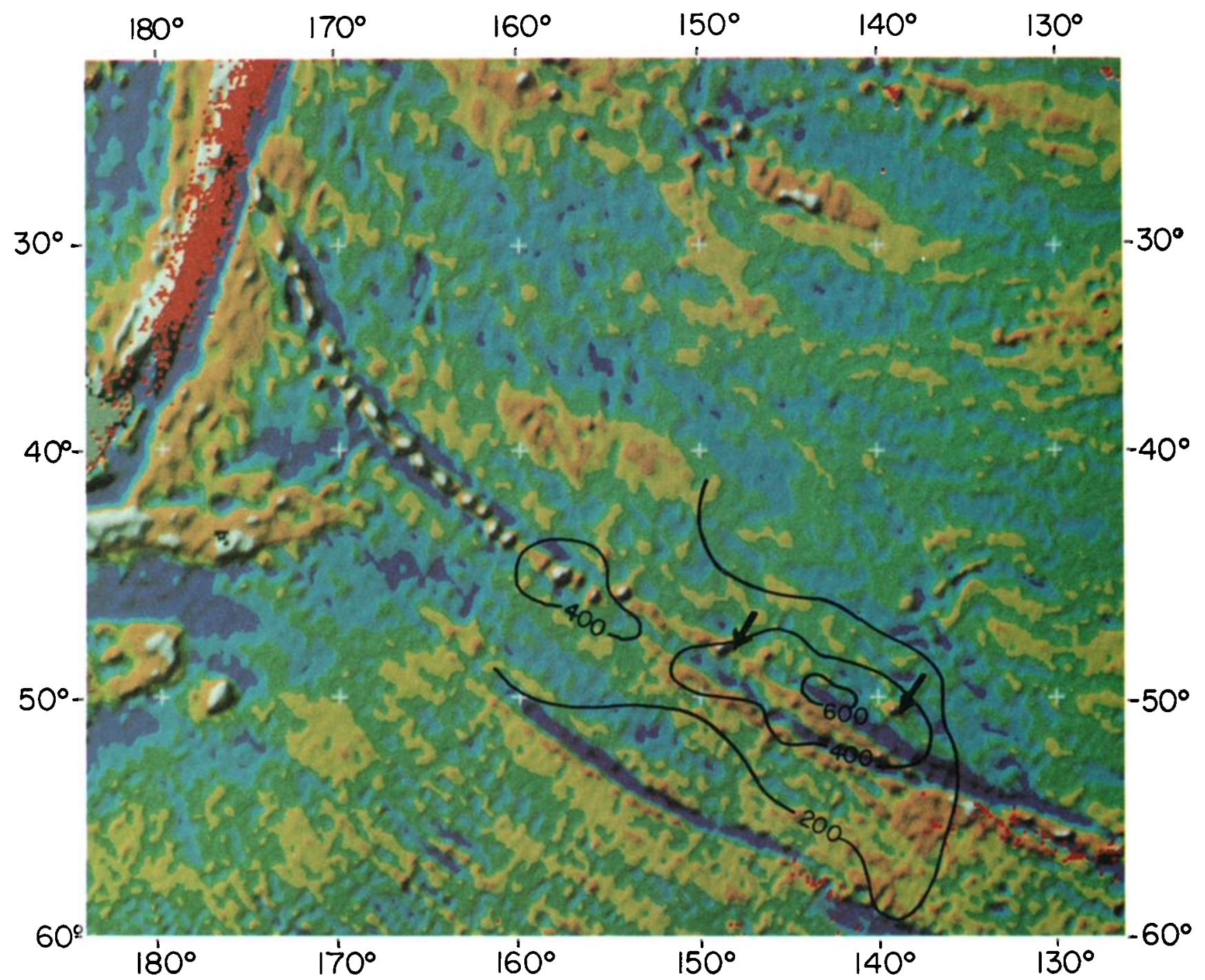

Plate 2 [Watts et al.]. Satellite-derived gravity anomaly map of the Louisville Ridge and vicinity. Epicenters for shallow earthquakes are shown in red. Residual depth anomalies are shown at $200-\mathrm{m}$ intervals and are based on works by Menard and Dorman [1977], Crough [1983], and this study. 